\title{
Anmeldelser
}

Günter Weitling: Die historischen Voraussetzungen des KIrchlichen Vereins für Indre Mission In Nordschleswig« und dessen Verbindung zur reichsdänlschen Indre Mission bis zur Jahrhundertwende.

Udgivet i 1. skriftrække af *Verein für Schleswig-Holsteinische Kirchengeschichte*, Flensborg, 1971.

Det er baggrunden for den nordslesvigske indre missions tilblivelse i 1887 og baggrunden for spaltningen af foreningen i 1912, der er hovedemnerne $\mathrm{i}$ denne bog, der er antaget som dissertation ved universitetet i Kiel.

I de to første kapitler behandles de historiske forudsætninger for bevægelsen. Der er to spændingsmotiver, som hele tiden vender tilbage i vækkelsesbevægelserne i Nordslesvig.

I vækkelserne er der tale om et overnationalt fællesskab. En troende dansker føler sig mere knyttet til en troende tysker end til en vantro dansker. Politik er noget verdsligt, der bør forsages.

Derved adskiller de vaktes kreds sig fra frimenighedsbevægelsen og fra tyskhedens kirkelige bestræbelser, der ligner hinanden deri, at de har et stærkt nationalt islæt. Ligheden betones af Weitling nıasse vel stærkt (»ähnlich wie« s. 26) på bekostning af forskellen. Frimenighederne formåede dog at skabe et kirkeligt liv. De tyske i Nordslesvig havde - som Weitling selv skriver - ikke uden grund ry for ukirkelighed.

Det nationale kunne dog også for vækkelserne blive et problem. Om holsteneren Bruun v. Neergaard, der efter 1864 i sin korte tid som præst i Aller utrætteligt virkede for at skabe vækkelse, bruges det stærke udtryk, at han »strandede på det nationale spørgsmål . "Kirkelig forening til Guds riges fremme i Slesvig“, stiftet 1868 af nogle præster i Nordslesvig, døde hen, da dens leder nægtede at bede for tysk sejr i 1870 og derfor måtte opgive sit embede.

Det andet spændingsmoment vedrører lægfolkets deltagelse i vækkelsesforkyndelsen. Øvrighedens og gejstlighedens - ikke helt ubegrundede - frygt for sekteriske tilbøjeligheder hos lægfolket fulgte vækkelsesbevægelserne lige fra den gamle pietisme, hvis huslige opbyggelsesmøder af regeringen blev stillet under gejstligt tilsyn ved konventikelplakaten i 1741, til Rinkenæspræsten Emil Wackers 
missionsforening i 1875, hvor præsterne afviste samarbejde med lregfolk.

En vækkelsesbevægelse, hvor lægfolket stod i bevidst opposition til gejstligheden, var den "Gemeinschaftsverein «, som slesvig-holstenske bønder stiftede i 1857 . Præster blev kun optaget som "brødre«, ikke i kraft af deres gejstlige embede. Ganske vist havde foreningen som formand fra 1873 baron Jasper v. Oertzen, der som gammel officer mente, at præsterne $i$ vækkelsesarbejdet hverken skulle være i eller bag fronten, men foran fronten. Men alligevel havde bevægelsen ved hans død i 1892 fjernet sig fra kirken i flere lærepunkter og brød året efter helt med landskirken.

$v$. Oertzen spillede en vis rolle, da »Kirkelig forening for indre mission i Nordslesvig « blev stiftet. En tysksindet kommuneforstander, Chr. Holm i Aller, bad ham begynde et lignende arbejde som i Holsten og Sydslesvig med dansktalende læapræedikanter; v. Oertzen fik Vilh. Beck til at tillade en af den danske indre missions folk, Lars Birk, at tage et arbejde op i Nordslesvig. I forståelse med $v$. Oertzen, og med ham som medlem af bestyrelsen, blev foreningen oprettet i 1887. Men det blev ikke v. Oertzens "Gemeinschaftsverein «, der blev den nye forenings forbillede. Det blev »Kirkelig forening for indre mission i Danmark «.

Det var ikke nationalt sindelag, der knyttede lederne (5 præster og 2 lægmænd) til den danske indre mission. De var alle "deutscher Gesinnung «. Men præsteseminariet i Haderslev havde givet flere af dem forståelse for Nordslesvigs specielle forhold. I ovrigt kan der påvises et broget spil af impulser hos dem. $\mathrm{P}_{a}^{\circ}$ tyske universiteter havde flere af dem stået under indflydelse af pietistiske og ortodokse professorer. En stor rolle spillede den lokale slesvigske baggrund: gammel slesvigsk pietisme, Christiansfeld, Breklum og den før nævnte forening fra 1868. Meget afgørende blev indflydelsen nordfra gennem Vilh. Beck. Præsten i Højrup, Nic. C. Nielsen, var flere gange rejst over grænsen for at høre Beck prædike. Diakonen i Ảbenrå Hans Tonnesen havde på biskop Godts tilskyndelse studeret Grundtvig og i øvrigt hos Vilh. Beck fundet frugtbar udnyttelse af det bedste hos Grundtvig og Kierkegaard. H. C. S. Lawaetz, prest i Ulkebøl, havde kontakt med Vilh. Beck gennem sin broder $i$ Kalundborg, der var nær ven af Beck.

Derfor var det naturligt, at man på foreningens første årsforsamling i Åbenrå 1887 lod ikke blot Oertzen, men også Vilh. Beck prædike.

Foreningen mødte de samme to problemer som de tidligere vækkelser.

Udfra den traditionelle uvilje mod lægprxdikanter bad halvdelen af de nordslesvigske præster kultusministeriet forbyde lægfolks prædikevirksomhed. Imidlertid blev det missionærerne forbudt at virke 
$i$ et sogn uden præstens tilladelse. $P_{a}^{\circ}$ foranledning af lederen af Flensborg diakonissestiftelse, Emil Wacker, sikrede man sig yderligere mod afvigelser fra kirkens lære ved at give missionærerne en grundig indføring $i$ en lærebog $i$ kristendom, som Wacker udgav til dette formål. Resultatet var, at i 1910 var der næppe nogen prest, der forbød foreningen at virke i sit sogn.

Medens Tonnesen får den anerkendelse, at han med pædagogisk dygtighed førte tilsyn med missionærerne, får Wacker æren for, at den nordslesvigske indre mission blev en kirkelig forening, der stræbte mod samling om søndagens menighedsgudstjeneste og om dåb og nadver.

Indre mission i Nordslevig var fra begyndelsen neutral i national henseende. Der står $\mathrm{i}$ instruksen for missionærerne udtrykkeligt, at de $\mathrm{i}$ den nationale og politiske kamp tydeligt skal tilkendegive den indstilling, at Guds riges komme er deres eneste mål.

Foreningen blev med stigende styrke angrebet for sin neutrale holdning. Man følte det smerteligt at se den arbejde hånd $\mathrm{i}$ hånd med tysk fødte og tysk uddannede prester, der som tyske embedsmænd af den tyske regering lod sig bruge i fortyskningens tjeneste. Indre mission gjorde "med fromme ord « mennesker ligegyldige for deres folkelige forpligtelse, så de afbestilte aviserne og holdt sig fra valgene - eller måske endda gav regeringens kandidater deres stemmer. H. P. Hanssen så det som en af de vigtigste nationalpolitiske opgaver at nationalisere den nordslesvigske indre mission.

Det er Weitlings tese, at opgøret i Danmark om forholdet mellem kristendom og folkelighed afgørende har været medbestemmende for den nordslesvigske indre missions bevægelser i forholdet til det nationale (s. 123). Derfor lægger han afgerende vægt på at efterspore Becks stilling til den nationale kamp.

$\mathrm{Da}$ Beck deltog $\mathrm{i}$ foreningens forste årsforsamling i 1887, var det hans overbevisning, at arbejdet kun kunne lykkes ved at holde sagen udenfor $»$ dette flade politiske liv, hvor alle livets store spørgsmål tvinges ned $\mathrm{i}$ disse to flade rubrikker, om det passer til "Højrepolitik « eller til »Venstrepolitik «. Beck så altså nationalitetskampen i lys af provisorietidens politiske kampe i kongeriget. Han gjorde sig skyldig $i$ en "fejlfortolkning" når han betegnede den nordslesvigske situation som "nøjagtig ligesom i Danmark «. Angrebene på foreningen afviste Beck med den erklaring, at bevægelsen ville begå »åndeligt selvmord “, hvis den lod sig bruge i den nationale kamp.

Becks stilling ændredes gradvist, indtil han endelig $i$ en artikel $i$ 1898 erklærede, at msand dansk følelse, kærlighed til vort land og vort folk er ikke politik, men noget langt større og dybere end politik; det er en af de største og dybeste menneskelige følelser, som intet troende menneske kan fornægte uden at lide skade på sin kristendom«. Denne udtalelse lader sig ikke forene med standpunktet 
1887. Der var sket, hvad Weitling kalder „Becks kopernikanske drejning «.

Ârsagen til denne drejning finder Weitling deri, at de politiske forhold i Danmark var ved at normaliseres efter provisorietiden, og dermed ændredes også forudsætningen for Becks tidligere fejlagtige vurdering af den nationale kamp. Endvidere skulle baggrunden være en stigende aktivitet i Becks gode ven, Johs. Clausens grundtvigskprægede grænsemissionske arbejde og Clausens indlæg $i$ en debat $i$ »Kristeligt Dagblad «. Clausen skulle altså have haft afgørende indflydelse på Becks ændrede standpunkt.

Men på den anden side hævder Weitling, at Becks artikel 1898 skabte endegyldigt de latent tilstedeværende forudsætninger for en nationalpolitisk virksomhed fra indre missions side. I Nordslesvig, hvor man stadig fulgte rørelserne $i$ den rigsdanske forening og betragtede Beck som bevægelsens "åndelige fader «, bidrog den nye kurs til, at det nationale opgør trængte ind $i$ foreningen, og at vennerne af indre mission deltog livligere $i$ valgene. Indre mission var blevet et "politikum«. Ved den rigsdanske indre missions indflydelse havde den danske nationalfolelse, der var kaldt til live ved Grundtvigs virke, og som efterhånden også gennemtrængte indre mission, gjort et fremstod i Nordslesvig.

Men ved denne drejning havde Beck hjulpet med til at mane det selvmord frem, som han tidligere profeterede om. Dermed var forudsætningen skabt for bruddet $\mathrm{i}$ 1912, da bevægelsens tysksindede præster skilte sig ud som "Det gamle budskabs indre mission ", medens Hans Tonnesen blev hos den dansksindede fløj, idet han måtte erkende den dansksindede befolknings ret til "at kæmpe sin nationale kamp ud fra troens kristne stade«.

Weitling finder bogens tyngdepunkt $\mathrm{i}$ dette afsluttende kapitel om overgangen til den nye kurs. Der er fængslende dramatik over dette afsnit. Alligevel kan man ikke værge sig imod det spørgsmål, om det er tilstrækkeligt dokumenteret, at den afgørende årsag til, at den nordslesvigske indre mission ændrede kurs, er "Becks kopernikanske drejning «, og om ikke påvirkningen i lige så høj grad er gået fra Nordslesvig til kongeriget. Weitling mener selv, at Johs. Clausen har haft afgørende indflydelse på Becks omslag (s. 138). Begivenhederne i Nordslesvig skulle i sig selv være nok til en kursxndring. H. P. Hanssen skriver, at mange nordslesvigske folk blev vakt til eftertanke over det nationale spørgsmål ved Köllerpolitikken og ved at se et kuld yngre tysksindede præster rykke ind $i$ præstegårdene.

Dette spørgsmål vil måske kunne belyses nærmere ved en videregående undersøgelse, ligesom man må håbe, at selve bruddet i 1912 vil blive taget op til behandling. Foreløbig er der med denne bog givet en sober og velskrevet skildring af forhistorien, og $\mathrm{i}$ øvigt en pietetsfuld skildring af livet i de missionske kredse. 
Fremstillingen bygger overvejende på trykt materiale. Det nye er en flittig brug af den nordslesvigske presse. Det er velgørende, at Weitling holder sin egen person i baggrunden og kun ét sted ganske naturligt - markerer sit syn på det nærgående problem, som hele sagen drejer sig om: det teologisk korrekte er fremført af Tonnesens fløj, hvorimod bevægelsens særlige nådegave under de givne forhold là deri, at man ikke stillede de nationalpolitiske forhold $\mathrm{i}$ forgrunden og gjorde dem til erstatningsreligion.

Det er et stort savn ved den udmærkede bog, at den mangler et personregister.

\section{Asger Nybolm.}

\section{Wolfgang Prange: Die Anfänge der grossen Agrarreformen in Schleswig-Holstein bis um 1771.}

Quellen und Forschungen zur Geschichte Schleswig-Holsteins, Band 60, (Karl Wachholtz Verlag, Neumünster, 1971), 728 s.

I skriftrækken Quellen und Forschungen zur Geschichte SchleswigHolsteins, hvor så mange fremragende bidrag til Sønderjyllands historie i tidens løb er blevet udgivet, foreligger der nu også et digert værk om de store landbrugsreformer i Slesvig og Holsten indtil 1771. Ikke mindst, fordi forfatteren også behandler de nordslesvigske forhold, må et sådant værk vække stor opmærksomhed her $\mathrm{i}$ landsdelen. På dansk har vi i forvejen bl. a. Troels Finks meget benyttede bog fra 1941 om udskiftningen i Sønderjylland indtil 1770, men dels behandler Troels Fink kun en del af de emner, som Prange tager op i sin bog, dels griber de sagen an på vidt forskellig måde. Medens Troels Fink stort set inddeler sin bog efter problemstillinger og behandler disse problemstillinger for Slesvig som helhed med beskrivelse af alle de forskelligheder, der er fra egn til egn, så har Prange valgt at behandle hvert område for sig og - som han selv siger $i$ indledningen - uden mange sideblikke og uden at tilstræbe et fælles skema for beskrivelsen af hvert enkelt område. Kun således mener han, at en sagligt forsvarlig fremstilling, der tager hensyn til landets mangfoldighed, er mulig. Vi făr altsà en række afsnit, der sådan set godt kunne stå alene hver for sig, fordi de egentlig ikke er forbundet med hinanden på anden måde, end at de findes i samme bog, og ved at der til sidst (s. 591-662) bringes en samlet oversigt. Det er karakteristisk for forfatterens arbejdsform ved denne undersøgelse, at afsnittene mange gange igen deles op $\mathrm{i}$ en række nxsten selvstændige artikler, $f$. eks. når talen er om nedlæggelsen af de kongelige ladegårde, hvor omtrent hver ladegård får sit eget lille afsnit. Resultatet bliver $i$ nogen grad, at bogen synes at falde fra hinanden, et indtryk, som det sammenfattende afsnit til sidst $i$ bogen ikke helt formår at udslette. Men samtidig må det siges, at systemet 
også har sine fordele. Ved $\mathrm{i}$ hvert afsnit kun at behandle et område, der er ensartet med hensyn til lovgivningen, myndighedernes holdning til reformerne og - ikke mindst - kildematerialets art, er det muligt at skildre udviklingen $\mathrm{i}$ dette område med en konsekvens og klarhed, som ellers ikke ville have været mulig. På dette punkt er det foreliggende værk da også forbilledligt.

Pranges bog er et imponerende værk. Med stor detaljerigdom skildres, hvad der skete. Hvorfor det skete, får man derimod mindre at vide om. Det kunne ellers have været interessant at fà lidt mere at vide om, hvilke tanker man gjorde sig, hvorfra ideerne kom, hvordan de første eksempler virkede på de øvrige områder, hvorfor nogle områder var så længe om at følge efter osv. Men det er nok meget vanskeligt at nå til klarhed på disse punkter. Hovedvægten er $\mathrm{i}$ hvert fald lagt på at beskrive det mere håndgribelige. $\mathrm{Da}$ anmelderen har haft yderst kort tid til sin rådighed, er en vurdering af kildebenyttelsen ikke forsøgt, men udvælgelsen af kilder til det nordslesvigske område synes at være tilfredsstillende. Forfatteren henviser frejdigt til Trap, hvilket ikke anses for særlig god tone i dansk videnskabelig litteratur, da det i øvrigt udmærkede værks karakter af oversigtsværk opfordrer til at gå til mere primært materiale, men de anvendte afsnit skal nok være udmærkede. At gøre ophævelser over dette punkt ville nok være for småligt.

Værket er sparsomt illustreret med udmærkede kort, men underligt nok er ikke et eneste originalt udskiftningskort gengivet måske af tekniske årsager? Som bilag bringes meget nyttigt en del vigtige aktstykker, og endelig findes der et udmærket stedregister. Meget rosværdigt og til stor hjælp for danske læsere er det, at de nordslesvigske stednavne også bringes i deres danske form.

Pranges værk bringer et væld af gode oplysninger og bor finde mange benyttere. Ikke mindst de nordslesvigske lokalhistorikere må være opmærksomme på den nytte, de kan have af bogen.

Viggo Petersen.

Gerd. K. Kopper: Zeitungsideologie und Zeitungsgewerbe In der Region. Eine Fallstudie zu den politischen und Strukturbedingungen der Konzentration in Schleswig-Holstein 1945-70.

(Bertelmann Universitätsverlag 1972), 235 s.

Kampen om kontrollen, økonomisk og politisk, med efterkrigstidens vesttyske massemedier har of te været hård. Man behøver blot at minde om den heftige debat om pressekongen Axel Springers stadigt voksende imperium. Den omfattende mediedebat i forbundsrepublikken og den ofte bitre principdebat om massemediernes rolle $i$ det demokratiske samfund har især behandlet kontrolproblemet: 
hvordan sikrer man reel ytringsfrihed og alsidighed $i$ en verden, hvor massemedierne i stigende grad koncentreres på ganske få koncerner.

De borgerlige og rent kommercielle bladforlæggere forfægter naturligvis nok som deres standpunkt, at den frie ejendomsret bedst sikrer pressefriheden. Socialdemokraterne i forbundsrepublikken, der, som man også ser i Danmark, har været mindre heldige med at drive aviser pă rentabel måde, har $i$ langt højere grad interesseret sig for monopolkontrol i pressen, så man eliminerer uheldige følger af den stærke pressekoncentration.

Gerd. Koppers bog om presseudviklingen i Slesvig-Holsten er et tankevækkende, stimulerende og of te polemiserende bidrag til denne diskussion, her ført på regionalt plan.

Den er bygget op som en skildring af det møjsommelige genopbygningsarbejde efter 1945, giver en kort og klar gennemgang af de vanskelige forhold under det britiske besættelsesstyre og endelig en redegørelse for den økonomiske udvikling, der har medført den stærke pressekoncentration siden besættelsesstyrets ophør.

Kopper har udnyttet et nyt materiale, møjsommeligt skrabet sammen fra Slesvig-Holstens aviser og suppleret op med interviews. Men, som han også selv erkender, har pressens herrer ikke nogen overdreven meddelelsestrang, når det gxlder egne forhold og interesser.

Kopper er som samfundsvidenskabeligt orienteret forsker mere interesseret $\mathrm{i}$ grupper, strukturer og lange udviklingslinjer, mindre $\mathrm{i}$ specifikke historiske hændelsesforløb eller historiske personligheder, hvilket er lidt synd, da han sikkert også her har indsamlet et solidt materiale.

Således ville det have været interessant at se en karakteristik af chefredaktør Dr. Hanno Schmidt, Flensburger Tageblatt, eller L. P. Christensen, da han behandler den tidlige udvikling i Flensborgs presse så udførligt.

Koppers mest interessante afsnit er uden tvivl gennemgangen af den delikate periode under britisk styre. Han gennemgår omhyggeligt de forskellige faser, fra afnazificeringen til licenspressen, den af besættelsesmagten godkendte presse, og til liberaliseringen, der fulgte med afskaffelsen af besættelsesstyret. Afviklingen at licenspressesystemet til fordel for en ukontrolleret kommerciel presse blev begyndelsen til den stærke pressekoncentration. De nationalsocialistiske bladforlæggere, der gennem det britiske licenssystem havde været udelukket fra pressen, fik atter frit spil.

Kopper har gennemgået bladdøden $\mathrm{i}$ de forskellige hovedområder, Kiel, Flensborg osv. Han konstaterer i sine interessante, meget polemiske analyser af presseudviklingen i Slesvig-Holsten, at offentligheden $\mathrm{i}$ denne region, ikke mindst kommunalpolitisk og lokalt, 
på grund af den eksisterende koncentration får en meget indskrænket orientering om relevante forhold.

Koppers bog vil næppe blive yndlingslæesning $\mathrm{i}$ borgerlige kredse i Slesvig-Holsten, dertil er den for polemiserende. Men den er ikke desto mindre en nyttig bog, først og fremmest på grund af den fængslende gennemgang af tiden 1945-1951. Tilbage bliver blot at nævne, at det tjener til forfatterens ros, at han også har interesseret sig for Flensborg Avis og Südschleswigsche Heimatzeitung i deres naturlige sammenhæng.

Anders Ture Lindstrøm.

\section{Rudolf Asmus og Erich Maletzke: Das Haus an der Förde. 25 Jahre Schles- wig-Holsteinischer Landtag 1947-72.}

Med forord af fhv. ministerpræsident, landdagspræsident Dr. Helmut Lemke.

Nok har regionen Slesvig-Holstens skæbne gennem tiderne beskæf tiget mange historikere, men udviklingen i nyere tid er endnu noget forsømt. Derfor er det i sig selv prisværdigt, at den slesvigholstenske landdag fejrer sit 25 års jubilæum med udgivelsen af en slags landdagshistorie. Det er en statelig jubilæumsbog med mange illustrationer, forfattet af de to kendte slesvig-holstenske journalister Asmus og Maletzke. Skildringen er af forfatterne bevidst gjort populær, så den er tilgængelig for en bredere læserkreds. Den foregiver ikke at være og skal derfor ikke bedømmes som en videnskabelig afhandling.

Dette forhindrer dog ikke visse principielle betragtninger om værket. Uden at være for pedantisk kan man godt påpege forskellige forhold, der burde have været inddraget bedre i fremstillingen. Men først indholdet:

Landdagshistorien giver en bred skildring af den britiske besæettelsestid, et afsnit, der er noget af det bedste i bogen, fordi det giver en virkelig fornemmelse ikke blot af de politiske forhold, men også af stemningen. Den behandler omhyggeligt hver periode mellem landdagsvalgene og hovedtræk $\mathrm{i}$ lovgivningen $\mathrm{i}$ de 25 år. Men selv om de politiske og okonomiske problemer ikke undgås i fremstillingen, får man alligevel det indtryk, at jubilaumsbogen har affarvet de slesvig-holstenske problemer en del. Man får f. eks. ikke tilstræekkeligt indtryk af den permanente krisetilstand, Slesvig-Holsten befandt sig $\mathrm{i}$ indtil ind $\mathrm{i}$ halvtredserne. Ogsa den grænsepolitiske udvikling er utilstrækkeligt behandlet.

Danmark og det danske mindretal i Sydslesvig såvel som SSV er naturligvis nævnt, men ikke på særlig tilfredsstillende måde. Man interesserer sig i Slesvig-Holsten så meget for brobygningsfunktionen til Skandinavien, så skulle man nok have kunnet overkomme et sammenhæengende kapitel om udviklingen 1945-1955-1972. 
Det er beklageligt, at de biografiske oplysninger om landdagsmedlemmerne er så korte, at de nærmer sig det intetsigende.

Litteraturlisten er endnu sparsommere end den eksisterende litteratur om Slesvig-Holstens nyeste udvikling. Skal man have en litteraturliste med $i$ et sådant jubilæumsværk, må det være et rimeligt forlangende, at den kan bruges. En række kendte, for SlesvigHolsten relevante bøger, er ikke blevet nævnt. Således er Lorenz Rerups og Troels Finks bøger om grænselandet ikke taget med, ligesom Ernst Siegfried Hansen er blevet ignoreret. Heller ikke Heins Josef Varains bog om partier og interesseorganisationer er kommet med.

Forfatterne har leveret et meget velskrevet rids af 25 års landdagspolitik i Slesvig-Holsten, men den er for meget orienteret mod de lyse sider $\mathrm{i}$ udviklingen. Det skulle have varet muligt at behandle Slesvig-Holstens ofte svære problemer i perioden noget grundigere uden at svigte den populariserende opgave.

Anders Ture Lindstrøm.

\section{H. V. Gregersen: Laurids Skaus brevveksling med politiske venner}

\section{Sonderjylland. 1-II.}

Udgivet af Historisk Samfund for Sønderjylland. (936 sider).

I 1966 udsendte lektor H. V. Gregersen $i$ et stort bind på over 700 sider en del af brevene til og fra Laurids Skau. Brevvekslingen var navnlig med Skaus politiske venner i København. Bindet var interessant liesning, hele udgivelsesapparatet var forbilledligt, og man så med forventning frem til den bebudede forts $x$ ttelse, brevvekslingen med de politiske venner i Sønderjylland, der nu foreligger $i$ to vægtige bind.

Brevene her $\mathrm{i}$ de to nye bind er til og fra Christian Flor, Johan Wegener, Peter Hiort Lorenzens børn og Laurids Skaus egne sønner. Det kan ikke skjules, at bindenes titel ikke er særlig heldig. Christian Flor er vel nok en "politisk " ven, men Johan Wegener var alt endet end politiker, og Hiort Lorenzens børn og Skaus egne børn var ikke knyttet til Skau med politiske bånd. Yderligere opholdt Flor sig, mens korrespondancen med Skau stod på, hovedsageligt $i$ Kiel og $i$ udlandet; af brevene fra Wegener stammer vist ikke et eneste fra Sønderjylland. Hvad endelig de to grupper af "børn" angår, så var også de for det meste alle mulige andre steder henne end i Sønderjylland. Titlen betyder imidlertid mindre, værkets kvalitet anfægtes ikke heraf.

Skaus brevveksling med Kiel-professoren Christian Flor begyndte i 1839 , da den unge bonde forsigtigt nærmede sig den larde og fornemme herre, den fortsatte nogenlunde ubrudt til 1851-52, 
da Christian Flor rejste til udlandet, vred over ikke at have fået det embede som leder af Sønderjyllands kirke- og skolevæsen, som blev tildelt T. A. J. Regenburg. Det drejer sig altså om breve fra nogle af de år, da kampen mellem dansk og tysk nationalitet i hertugdømmet førtes hæftigst, og brevene er vekslet mellem to af de personer, der var fremme $i$ den allerførste kamplinje. Brevene er, som man under disse omstændigheder kunne vente det, aldeles fremragende som kilder til forstaelse af, hvad det var, der bevægede folk til at kaste sig ind i denne kamp. Ikke blot den specielt sønderjyske historie belyses, men også den europxiske nationalisme kan her ses i sin fuldstændige udvikling $\mathrm{i}$ disse breve mellem den lærde og intellektuelle universitetslærer og den folkelige og praktiske bonde. De mange detaljer om rent lokale forhold gør disse Flor-Skau breve til dele af den lille historie, deres nationalt brændende grundtone gør dem til stor historie. Hovedparten af brevene har været trykt før, fuldstændigt eller i udtog. Dette forklejner ikke udgavens værdi; det er væsentligt her at kunne se hele Flor-Skau brevvekslingen $\mathrm{i}$ sin fulde udstrækning, uden forkortelser og sammen med Skaus anden korrespondance.

I sammenligning med brevene til og fra Flor er de efterfølgende breve af mindre betydning for den politiske historie. Johan Wegeners politiske betydning var koncentreret om hans korte tid som forstander på Rødding højskole i nogle måneder af 1844-45, og netop i disse måneder er der ingen breve. Ellers skrev Wegener sine breve, de går fra ca. 1845 og op til Skaus død, mens han sad som prxst i Halsted på Lolland. Wegener har, så vidt det kan ses, ikke været synderligt velorienteret om de politiske begivenheder, hans manglende politiske flair og noget opbrusende karakter har heller ikke gjort ham til en mand, der ville få hemmeligheder betroet. Som direkte kilde til den politiske historie kan Wegeners breve altså ikke bruges. De er derimod uhyre oplysende om, hvad der rørte sig i danske akademikere med hensyn til den slesvigske sag, de viser, hvordan den lokale hjemme-industri, kandestøberiet, har udfoldet sig rundt $\mathrm{i}$ præstegårdene. Iøvrigt bidrager brevene naturligvis også til billedet af Wegener selv, og Laurids Skaus breve er som altid læseværdige. Hvor Skau også i de senere àr befandt sig $\mathrm{i}$ et slags lærlingeforhold over for Flor, så møder vi ham i forholdet til Wegener som vejlederen, hvis løseste strøtanke blev taget meget alvorligt. Dette præger naturligvis de to pennevenners korrespondance, der er af og til noget næsten docerende i Skaus breve, mere eller mindre dulgt beundring i Wegeners.

Brevene til Peter Hiort Lorenzens børn, officeren Frits, juristen Hans Rudolf og døtrene Sophie og Mathilde, er vel nok de mindst interessante. Skau har ikke i synderlig grad betroet sig til disse unge mennesker, og de har ikke haft større sager at be- 
tro ham. Der er en del tidskolorit $i$ disse breve, og de er vidnesbyrd om Skaus tilsyneladende aldrig svigtende omsorg for sine venner. Ganske skamløst brugte Skau enhver forbindelse, enhver lejlighed for at få puttet Hans Rudolf ind $i$ et slesvigsk embede. Man ser her også Skau $i$ en ny rolle, nemlig i den som den erfarne, der kendte denne arge verden. Således rădede han f. eks. Hans Rudolf i 1859:

"Dine ytringer om dit forhold til Brockenhuus-Schack - gav mig nogen anledning til frygt. Sørg endelig for at stå på intim fod med denne unge herre, og selv om han har den indbildning, at han er din vejleder eller protektor, eller hvad det nu er, så skader dette dig ikke en smule, dels fordi alverden ved, at det blot kan være $\mathrm{i}$ formel henseende, da næppe nogen tiltror ham åndelig overlegenhed, dels fordi hans indberetninger ad privat vej meget let kan have en afgørende indflydelse pà din fremtidige stilling og $i$ alle tilfalde være dig overordentlig nyttige, dels af den grund, at han sikkert om meget kort tid bliver din amtmand og altså foresatte, hvis protektion ikke alene er nyttig, men heller ikke kan være krænkende for dig, aldenstund han er det ex officio. Lad ham derfor være $\mathrm{i}$ den indbildning, at han er din protektor. Hør ham ud med tålmodighed og gør siden, hvad du selv vil og finder rigtigt. Dette slags folk, som er fødte stormænd, sætter altid pris på at protegere, og dobbelt når de ikke selv er store lys «. Denne fremgangsmåde havde Skau selv anvendt og med betydeligt held.

Endelig er der brevene til og fra Skaus egne sønner, Peter, Jens og Knud. Brevene her giver et ganske uretoucheret billede af Laurids Skau, i forholdet til sønnerne har han ikke lagt mange bånd på sig selv. Man ser ham som den meget vrede far, men også som den, der for rasende op, hvis nogen trådte hans drenge for nær. Han udtrykker sig $\mathrm{i}$ nogle af brevene med en xtsende hån, hudfletter de arme drenge på det grusomste med en ikke særlig tiltalende overlegen ironi, men er også dybt bekymret, når de er syge, stadig parat til at hjælpe, når noget går dem på. Nogen rar far at have har han dog ikke vxret, navnlig har hans ambitioner på sønnernes vegne været mere, end disse kunne bære. Der er også politisk stof $\mathrm{i}$ disse breve, mest detaljer om alle de praktiske ting, som Skau i årenes løb kom til at beskæf tige sig med og uhæmmede bemærkninger om de mennesker, som Skau arbejdede sammen med eller imod, men brevene er også vidnesbyrd om Skaus politiske hovedtanke: at sønderjyderne havde en ret til at være danske, og at denne ret ikke måtte tages fra dem.

Brevene er, som $\mathrm{i}$ "Brevveksling med politiske venner $\mathrm{i}$ København «, forsynet med et meget udførligt noteapparat. Der er en udførlig tidstavle over de begivenheder fra 1840 til 1864 , som er 
omtalt $\mathrm{i}$ brevene eller $\mathrm{i}$ noterne, der er et navneregister og en kronologisk ordnet brevfortegnelse, der omfatter sàvel de »københavnske" som de "sønderjyske « breve. Det er meget påskønnelsesværdigt, at lektor Gregersen har taget sig det store arbejde på, også at udarbejde et sagregister til bindene. Takket være det kan man hurtigt finde Laurids Skaus markante meninger om ting, som han satte pris på (opslagsord som skandinavisme eller fester) og ting, som han ikke brød sig om (opslagsord som aristokrati, godsejere eller drikkeri).

Det er en oplevelse at møde Laurids Skau i disse mange breve, han må have været et fantastisk levende menneske.

Jens Engberg. 


\section{Bognyt}

\section{lorn Piø: Folkeminde- og traditionsforskning.}

Dansk Historisk Fællesforenings håndbøger, 2. forøgede udgave, 1971, $100 \mathrm{s.}$

I denne ajourførte udgave er første kapitel, der har titlen: Folkeminder og tradition, og som $\mathrm{i}$ meget er en historisk redegorelse for denne forskningsgren, helt omskrevet og øget betydeligt i omfang. Nyere folkloristisk litteratur, der er fremkommet siden 1. udgave 1966, er anfort, og den nyttige lille bog er forsynet med et kombineret person- og sagregister.

P.K.I.

\section{A. Strange Nielsen: Lokalhistoriske arkiver.}

En vejledning for medarbejdere og benyttere med en indledning ved Johan Hvidtfeldt.

Dansk Historisk Fællesforenings håndbøger, 1972, 91 s.

Omsider er den nye, men længe ventede vejledning for medarbejdere $\mathrm{i}$ lokalhistorisk arkivarbejde udkommet, efter at den forste lille vejledning, der var udarbejdet af de lokalhistoriske arkivers grand old man, cand. pharm. Hans Brandt, Fåborg, allerede var udsolgt i 1959. Der har ved udsendelsen af vejledningen på grund af sygdom og frafald af medarbejdere varet forsinkelser, men nu foreligger den med skoleinspektor A. Strange Nielsens navn på titelbladet og med rigsarkivar, dr. phil. Johan Hvidtfeldt som forfatter af det indledende kapitel om offentlige arkiver, hvori bl. a. den grundsxtning understreges, at offentlige arkiver, altså også de kommunale, horer hjemme i statens arkiver, hvilken these jo har givet

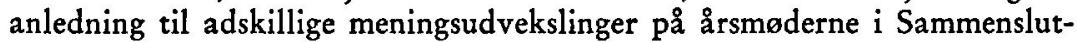
ningen af Lokalhistoriske Arkiver.

A. Strange Nielsen, der er nævnte sammenslutnings energiske formand, redegør for oprettelsen af de lokalhistoriske arkiver, hvoraf der ved bogens udgivelse var 97, men han er lidt utilfreds med, at der ikke er langt flere. Dog ser han på den anden side ikke gerne, at arkiverne kommer til at dakke for små områder. Små kommuner må gerne slutte sig sammen om et egnsarkiv. For den videnskabelige bruger vil dette være en fordel, da materialet derved er samlet på færre steder. Der peges på, at der endnu er ca. 200 primærkommuner uden tilhørsforhold til et lokalhistorisk arkiv, og der gives gode råd $\mathrm{m}$. h. t., hvorledes nye arkiver kan oprettes og organiseres. Der er forskellige muligheder. Den bedste skulle være, at arkiverne oprettes som afdelinger ved de kommunale biblioteker, hvorved 
der opnås understøttelse efter biblioteksloven på lige fod med bibliotekernes øvrige aktiviteter, men der findes dog også arkiver oprettet på foreningsbasis, som selvejende institutioner eller som museumsafdelinger, og disse etableringsformer er stadig mulige. Vigtigst for alle de lokalhistoriske arkiver er imidlertid, at uanset organisationsformen, må der være en gruppe interesserede personer, der tager sig af indsamlingen og registreringen, og som har eller formår at skabe de fornodne kontakter til befolkningen, uden hvilke arkiverne ikke kan trives.

Det afsnit, der nok er det vigtigste for de lokalhistoriske arkivers medarbejdere, er det, hvor der redegøres for ordningen og registreringen af det indsamlede materiale. Forf. opdeler samlingerne $i$ tre afdelinger: en personalhistorisk, en topografisk og en saglig, og alle sager, uanset om det er billeder, arkivalier eller tryksager, indordnes i dette skema. For en person vil man altså kunne forvente at finde $i$ et lag eller en pakke: billeder, arkivalier, avisudklip og evt. piecer. Ud fra rent bevaringsmæssige grunde vil mange dog sikkert sætte et spørgsmålstegn ved, om denne opbevaringsform er hensigtsmæessig. Såvel kemikalierester $\mathrm{i}$ fotografierne som blxksyren $i$ arkivalierne kan, hvis disse ikke er omhyggeligt afsondrede, foràrsage ulykker. $O g$ er det ikke uheldigt, hver gang man skal have fat $i$ et billede at skulle rode efter det imellem $\mathrm{i}$ forvejen måske mornede arkivalier og avisudklip. Bevaringsmæessigt og i mange henseender også arbejdsmxssigt vil det nok vere at foretrxkke, at sagerne primært sorteres efter art: billeder (positiver og negativer hver for sig), arkivalier og tryksager. I et museum anbringer man jo heller ikke en knipling og en plov i samme montre, selv om de stammer fra samme gård. Forf. afviger da også senere i bogen (s. 78) fra den tidligere så varmt anbefalede tredeling (s. 67), idet han anbefaler særlige anbringelsesformer for fotografiske plader og film, og i denne forbindelse nævnes også lydbånd. Den af forf. foreslåede tredeling af materialet forudsætter næsten også, at man ser lidt stort på proveniens (hjemhørs)-princippet, hvorom der ellers skrives så pæent andetsteds. Men det er ikke stedet her at gå $i$ enkeltheder med den på så mange måder nyttige vejledning. Sagen er jo den, at indsamling, opbevaring, ordning og registrering kan ske på forskellig vis, dels afhæengig af arkivskabernes personlighed og dels af arkivets størrelse og særlige interesseområder. Vigtigst er det, at sagerne bliver indsamlet og bevaret for eftertiden, og med denne målsatning for øje er vejledningen en god inspirator.

$$
\text { P.K.I. }
$$

\section{Carsten Bregenhøj: Etnologisk Interviewteknlk.}

Dansk Historisk Fællesforenings håndbøger, 1971, 88 s.

Indsamlingen af traditionsstof, folkloristisk og etnologisk materiale er opgaver, som lokalhistoriske arkiver og også mange lokal- og amatørhistorikere har taget op for egen regning. Mange, der har deltaget $i$ et sådant arbejde, har imidlertid følt savnet af en vejledning. Carsten Bregenhøj, 
der er medarbejder ved Dansk Folkemindesamling, har nu $i$ en lille instruktiv bog søgt at give denne hjæelp. Han går ud fra, at der ved indsamling af traditionsstof $\mathrm{i}$ dag $\mathrm{i}$ almindelighed vil blive anvendt båndoptager, og der gives derfor elementære, men gode råd om pasning og benyttelse af en sådan og om registrering og pleje af bånd, der skal være af god kvalitet. I fortsættelse heraf følger råd m. h. t. interviewteknik, herunder især nogle kloge ord om interviewets psykologi. Det understreges, at indsamleren må ofre megen tid på forberedelsen, og at det er af meget afgørende betydning for undersøgelsens heldige udfald, hvordan spørgsmålene falder. Der gives eksempel på et interview med forfatterens kritiske bemærkninger. Det kan måske nok indvendes mod bogen, som også mod enkelte andre $i$ serien, at den $i$ mangt og meget mere sigter på vejledning af studerende end på egentlige amatør- og lokalhistorikere. Man må være lidt varsom med ikke at forskrække amatørerne med at stille for store krav. Opmuntring og enkelte gode råd er bedre end alt for metodisk og teknisk belæring. I indledningen tales, som også $\mathrm{i}$ andre sammenhænge, om samarbejde mellem amatør og forskningsinstitution, og dette kan heller ikke let understreges for ofte, men s. 11 leverer forf. et uheldigt valgt eksempel på dårligt samarbejde. En amatør har sendt en videnskabelig institution et lydbånd og bedt institutionen udtale sig om, hvorvidt det havde interesse, og om han burde fortsæette undersøgelsen. Forf. kommer nu med den mærkværdige forklaring, at da båndet var af en anden slags end dem, institutionen bruger, prøvede man det på så mange båndmaskiner, at da det endelig lykkedes at finde en, der kunne afspille båndet, var det ødelagt. Man må vel imidlertid kunne forudsette så megen teknisk kunnen hos en forskningsinstitution, at man skulle kunne klare en sådan sag - ellers bør man rådføre sig med radioteknikere, inden der laves ulykker. For ellers er det vel bedre, at man giver amatørerne det råd at undlade at indsende bånd til forskningsinstitutionen, med mindre de $\mathrm{i}$ forvejen har sikret sig en kopi af båndet. Mod sin vilje har forfatteren leveret et fremragende eksempel på, hvorledes en forskningsinstitution ikke skal optræde i samarbejdet med amatører - en skønhedsplet på en ellers god og nyttig bog.

P.K.I.

\section{Renate Erhardt-Lucht: Die Ideen der Französischen Revolution in Schleswig-Holsteln.}

Quellen und Forschungen zur Geschichte Schleswig-Holsteins, Band 56, (Karl Wachholtz Verlag, Neumünster, 1969), 227 s.

Renate Erhardt-Luchts undersøgelse af den holdning, man i Hertugdømmerne indtog til de franske revolutionsideer $i$ årene 1789-99, er en skuffelse for læeseren. Dens oversigt over avisernes og tidsskrifternes indstilling til revolutionen kan være nyttig, men det samme kan ikke siges om bogens opregning af en rakke enkeltpersoners holdning til revolutionen. Dertil er disse personers meninger for velkendte og udnyttelsen af det 
forhåndenværende store kildemateriale for overfladisk. Der gøres således ikke et alvorligt forsøg på at skelne mellem adelens og borgerskabets holdning $i$ denne væesentlige sag (man når ikke ud over en konstatering af, at der var revolutionsvenner og -fjender $i$ alle befolkningslag). Kapitlet om regeringens holdning til de franske emigranter kaster ikke lys over det behandlede problem, og det afsluttende kapitel om revolutionens mulige indflydelse på tidens sociale uro hviler på et alt for spinkelt materiale.

Det synes at være en forhåndsantagelse hos forfatterinden, at man ud fra folkets manglende kendskab til politik kan slutte, at de revolutionære begivenheder i Frankrig ikke kan betragtes som hovedårsagen til urolighederne (kun tre tilfælde af social uro omtales). Hun synes ikke at have losst (eller ikke forstået) Johan Hvidtfeldts afhandling om den sociale og politiske uro i Nordslesvig i revolutionstiden (Sdj. Årb. 1945), selvom hun nxvner den $i$ en fodnote og $i$ sin litteraturfortegnelse. Hun burde $i$ hvert fald have taget stilling til Hvidtfeldts konklusion, der er modsat hendes egen: "Igennem århundreder havde der ikke været en sådan gærende uro og så utallige demonstrationer. Der er ingen tvivl om, at det er de store begivenheder i Frankrig, som har skabt de åndelige forudsætninger for urolighedernex.

Sønderjylland er $i$ det hele taget mere end stedmoderligt behandlet $i$ bogen. Der kan igen henvises til Hvidtfeldts afhandling, som giver et rigt og levende billede af striden mellem tilhxngere og modstandere af revolutionen $i$ Haderslev og i øvrigt peger på København som et punkt, hvorfra revolutionsideerne formidledes til Sønderjylland. Renate Erhardt-Lucht har ikke været opmxrksom på denne mulighed, der måske også vil vise sig at være frugtbar $i$ en undersøgelse af ideernes indtrxngen $i$ Flensborg.

Alt $\mathrm{i}$ alt må man håbe, at Renate Erhardt-Luchts bog ikke vil afholde andre forskere fra at beskæftige sig med dens interessante, men langt fra udtømte emne.

G. $J$.

\section{E. L. Parbøl: Altona-Klel, Christian den Ottendes Østersø-Jernbane.}

1972, 62 s., ill.

Dansk Jernbane-Klub har som nr. 30 i sin rakke af skrifter om danske jernbaner udsendt en lille bog af E. L. Parbel om Christian den Ottendes Østersø-jernbane Altona-Kiel, der var den første jernbane, som blev bygget i det danske monarki.

Indledningsvis berettes om færdselsmulighederne dengang, da man i 1832 kun en gang ugentlig kunne komme med en postvogn fra Altona til Kiel eller omvendt, en tur, der varede 24 timer, og om, hvordan der den 15. april 1836 af Frederik VI blev udstedt en koncession på en dampvognsrute på den nye landevej mellem Altona og Kiel og mellem Altona og Blankenese, men der meldte sig ikke nogen liebhavere. Kieler Correspondenzblatt var af den mening, at en dampvogn på chausseen mellem Kiel 
og Altona ville reducere projektet om en jernbane mellem Hamborg og Lybak til sin sande værdi.

Men det blev jernbanen, der sejrede. Ganske vist skulle der lange og svare drøftelser til, både om linjeføringen og af økonomisk art, men den 16. juni 1842 kunne Altona-Kiel jernbaneselskabet stiftes, og den 28 . juni 1842 underskrev Christian VIII jernbanens koncession, hvorefter det store arbejde kunne påbegyndes, og den 8. maj 1843 blev det første spadestik foretaget.

Østersøbanen blev indviet på kongens fødselsdag den 18. september 1844, og der kørte derefter to persontog og et godstog daglig $i$ hver retning.

Det skulle hurtigt vise sig, at banen var fuldt berettiget og blev benyttet i stort omfang.

Bogen skildrer herudover banens vogne og lokomotiver.

Endvidere berettes om organisation og personaleforhold, driftsforhold og toguheld, som man første gang var udsat for allerede den 30. september 1844, da det første togsammenstød fandt sted, dog uden nævneværdig skade, samt om signalvæsen, billetter, køreplaner, vognklasser og godstransport $\mathrm{m}$. $\mathrm{v}$.

Skildringen sluttes med en omtale af andre baneanlæg, som tilslutningsbanen fra Elmshorn til Glückstadt og senere videre til Itzehoe og fra Neumünster til Rendsborg, der havde endestation syd for Ejderen, men som senere ved anlægget af Rendsborg-Flensborgbanen fik forbindelse over Ejderen, hvorefter den oprindelige station forsvandt.

Bogen er illustreret dels med billeder af banegårdene i Altona, Kiel, Glückstadt og Rendsborg og af billetter fra banens første leveår samt af samtidige satiriske tegninger og folkelige tryk $\mathrm{m}$. v., herunder den erindringsmedalje, der blev släet af mønten i Altona af medaljør Alsing $i$ anledning af jernbanens åbning, og som på forsiden bærer Christian VIII's billede og på bagsiden billedet af et lokomotiv.

O. C.

\section{K. M. Hermansen: Skodborg sogn I Frøs herred.}

2. udgave, 1971, 268 s. ill.

Da første udgave af K. M. Hermansens bog udkom i 1947, blev den anmeldt her $\mathrm{i}$ årbøgerne, og det skal derfor blot nævnes, at der nu foreligger en ajourført udgave af denne i mange henseender ganske udmærkede sognehistorie. Den nye udgave adskiller sig kun lidt fra den oprindelige, men man har søgt at tage hensyn til de væsentligste af de xndringer, der er sket $\mathrm{i}$ løbet af det sidste kvarte århundrede.

V.P. 


\section{Noter og nyt}

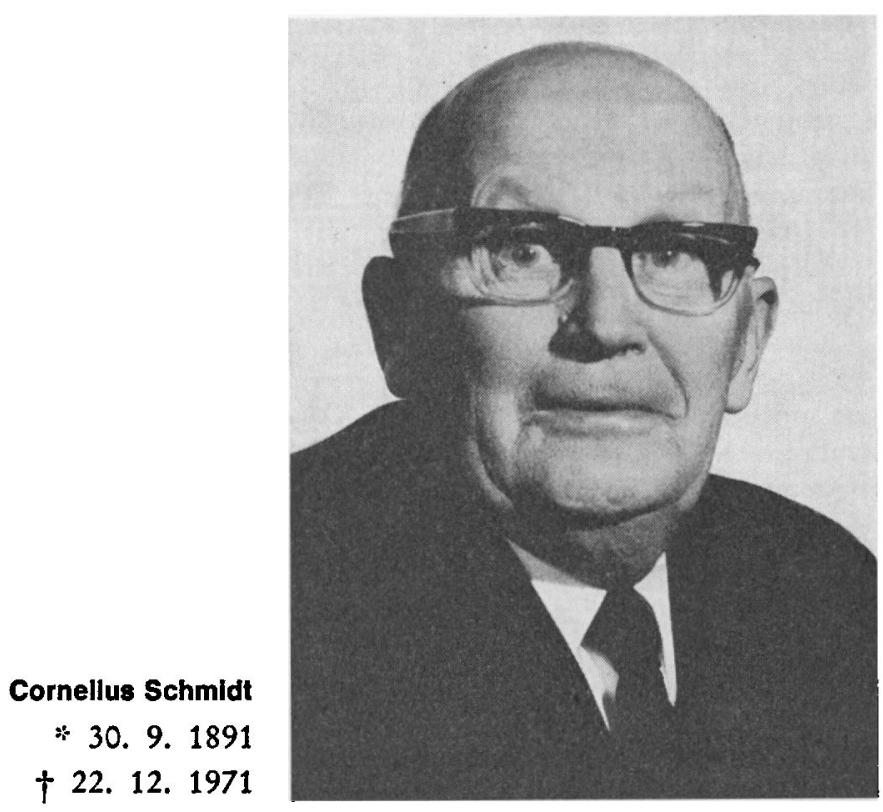

Den 22. december 1971 døde et trofast og interesseret medlem af Historisk Samfund for Sønderjylland, fhv. gårdejer Cornelius Schmidt, Døstrup.

Han fødtes den 30. september 1891 i Drengsted, hvor han overtog sin fødegård, da han i 1919 blev gift med Marie Carlsen fra Randerup. Men forinden måtte han som aktiv tysk soldat i Allenstein, Østprøjsen, ved første verdenskrigs udbrud med til ostfronten, hvor han lige før jul 1914 blev hårdt såret og lå et år på lazaret, hvorfra han blev hjemsendt som uduelig til krigstjeneste med en stærkt ødelagt venstre hånd.

Det stillede $i$ sig selv store krav $i$ de år at skulle drive en gård og efter genforeningen sætte sig ind i de nye driftsformer, men der kom hurtigt bud til den initiativrige unge mand om forskellige tillidshverv, bl. a. som bestyrelsesmedlem i det nyoprettede elværk for Bredebro og omegn og som medlem af bestyrelsen for Det blandede distrikts landboforening, hvor han i over 30 år blev en meget påpasselig og økonomisk kasserer. Ved udtrædelsen 
af sidstnævnte bestyrelse blev han udnæunt til æresmedlem, også som tak for veludført arbejde ved udgivelsen af jubilæumsskriftet til landboforeningens 100-års jubilæum i 1954, hvor undertegnede blev valgt til at assistere ham. Ved dette arbejde afdækkedes den store og dybtgående viden, Cornelius Schmidt havde om egnens og foreningens historie; mange gange har jeg og andre, der havde sluttet venskab med ham, siddet $i$ hans og Maries hyggelige stuer og hørt ham berette eller vise dokumenter frem, han havde fundet. Ikke mindst Døstrup skoles historie og de enkelte gårdes historie havde han et indgående kendskab til. Her efterlader han sig stof, som senere forskere kan drage nytte af.

Cornelius Schmidt var igennem mange år medlem af menighedsrådet $\mathbf{i}$ Døstrup og blev en god hjxlper og rådgiver under kirkens restaurering, hvor han knyttede nær kontakt til nu afdøde konservator Andersen. I grundforbedringsudvalget og $\mathrm{i}$ jordfordelingsudvalget lagde han en stor arbejdsindsats, og man drog her nytte af hans fremsynethed og hans evne til at kunne få en god, men vanskelig sag til at glide.

På dette sted vil det imidlertid være naturligt, om især hans indsats som amtsformand gennem 16 år for Tønderkredsen af Historisk Samfund erindres. Det var en opgave, der optog ham meget, og han skyede ingen anstrengelser for at holde kontakt ud $i$ sognene, ligesom han var en dygtig formidler af de tanker og planer, han havde med hjem fra styrelsesmøderne $\mathrm{i}$ hovedforeningen. Arbejdet for og med sønderjysk lokalhistorie var en sag, der lå ham meget på sinde, og jeg tror, at det inderst inde gjorde ham ondt, da han følte ikke mere at kunne gøre fyldest på grund af sin tiltagende svaghed.

$\mathrm{Vi}$, der har stået $\mathrm{i}$ arbejde sammen med ham, vil taknemmeligt mindes ham og samarbejdet med ham.

Søren Nissen.

\section{Landsarkivet for de sønderjyske landsdele, Abenrâ.}

Året 1971 vil først og fremmest indgå i Landsarkivets historie sum det år, da arbejdet med den store udvidelse påbegyndtes. Toftlund Byggeindustri A/S, der har overtaget beton- og murerentreprisen $\mathrm{m}$. v., begyndte udgravningsarbejdet den 28 . sept., og siden da er støbt $\mathrm{i}$ beton fire magasiner, to under og to over jorden. Fundamenter og gulv er endvidere stabt til foredragssal, lasesal, kontorer m. v. i hele stueetagen, hvor pillerne til den bxrende konstruktion endvidere er rejst. Skalmuringen med røde mursten er påbegyndt. I det indre er installationerne af varme, el og ventilation påbegyndt. Nybygningen vil være klar til indflytning omkring 1. maj, og derefter tages der fat på ombygningen af de gamle magasiner og kontorer. Denne ombygning skal vare afsluttet ved nytårstid 1973/74. Det har ikke helt kunnet undgås, at de besøgende er blevet lidt generet af byggeriet; navnlig $i$ regnvejrsperioder har det været lidt ubehageligt at skulle færdes fra de interimistiske parkeringspladser, men efter udgravningernes og kloakeringens 
afslutning skulle de værste gener for de besøgende være forbi.

Ved overflytningen fra den gamle bygning til de nye magasiner og kontorer $i$ april-maj nxste år vil det imidlertid nok blive nødvendigt at lukke for lasesalsbesaget i nogle uger. Nærmere meddelelse herom vil fremkomme i dagspressen.

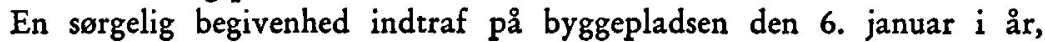
idet en af de tunge støbeforme, der normalt har måttet brydes løs fra betonvæggen med værktøj, pludselig løsnede sig og faldt over på arbejdsmand Jens Lund fra Over Jerstal. Han blev så hårdt medtaget, at han ved ankomsten til sygehuset var død af sine kvestelser. I landsarkivarens fraværelse var Landsarkivet repræsenteret ved bisættelseshøjtideligheden af arkivar Dorrit Andersen.

Det er forudset og godkendt af finansudvalget, at Landsarkivets personale efterhånden udvides med 10 personer. Foreløbig er med henblik på forberedelsen af flytningen ansat en arkivbetjent, Carl Aage Obeling. Trods det statslige personaleloft regnes der med ansettelse af bl. a. en bogbinder i finansåret 1973/74, idet bogbinderiet ellers ikke kan tages i brug.

I sidste årsberetning kunne der berettes om en mindre tilbagegang $\mathrm{i}$ ekspeditionen til læsesalen. I kalenderåret 1971 og i de sidste måneder har der igen været en stigende tendens. Over for et besegstal på 2062 i 1970 er tallet steget til 2150 i 1971, og antallet af ekspeditioner af arkivalier er $\mathrm{i}$ samme tidsrum steget fra 15146 til 19854. Udlånet til andre arkiver og biblioteker er steget fra 145 bd., pkr. og lxg til 1330, således at Landsarkivets udlån 1971 nxsten lå på højde med Rigsarkivets (1576). Indlånene var 1971116 enheder mod 189 i 1970. Af den ovrige statistik kan nevnes: Antallet af tilføjelser og rettelser i personregistre og kirkebøger var $1971514 \bmod 542$ i 1970, og tallene på tjenstlige undersegelser var 123 i 1971 , overfor 198 i 1970. En vældig stigning skete $i$ brugen af xeroxapparatet, idet der i 1971 blev fremstillet iklie mindre end 125480 kopier, hvoraf en betragtelig del udfortes for Historisk Samfund for Sønderjyllands regning og ved dettes arbejdskraft. 1970 var produktionen af xeroxkopier 55948, og i indeværende år vil man igen være nede på et mere normalt antal. Mange besøgende benytter sig af den lette og billige adgang til at få kopier af arkivalierne, men xeroxapparatet finder dog forst og fremmest anvendelse til fremstilling af kopier til brug på lasesalen af de mest benyttede arkivalier. Kopieringen af de $x$ ldre hovedministerialbøger og af registre til skyldog panteprotokollerne er afsluttet, og kopieringen af kontraministerialbøgerne fra købstæder og flækker er godt i gang.

Som $\mathrm{i}$ de nærmest forudgående år har afleveringen fra statslige og kommunale myndigheder været meget beskeden. I alt er der 1971 blevet afleveret 1174 bd., 1091 pk. og 37 stk., der tilsammen fyldte 132 løbende hyldemeter. Disse sager har kunnet anbringes $i$ det $i$ sidste årsberetning omtalte depot i Tønder og i Landsarkivets anneksbygning. 


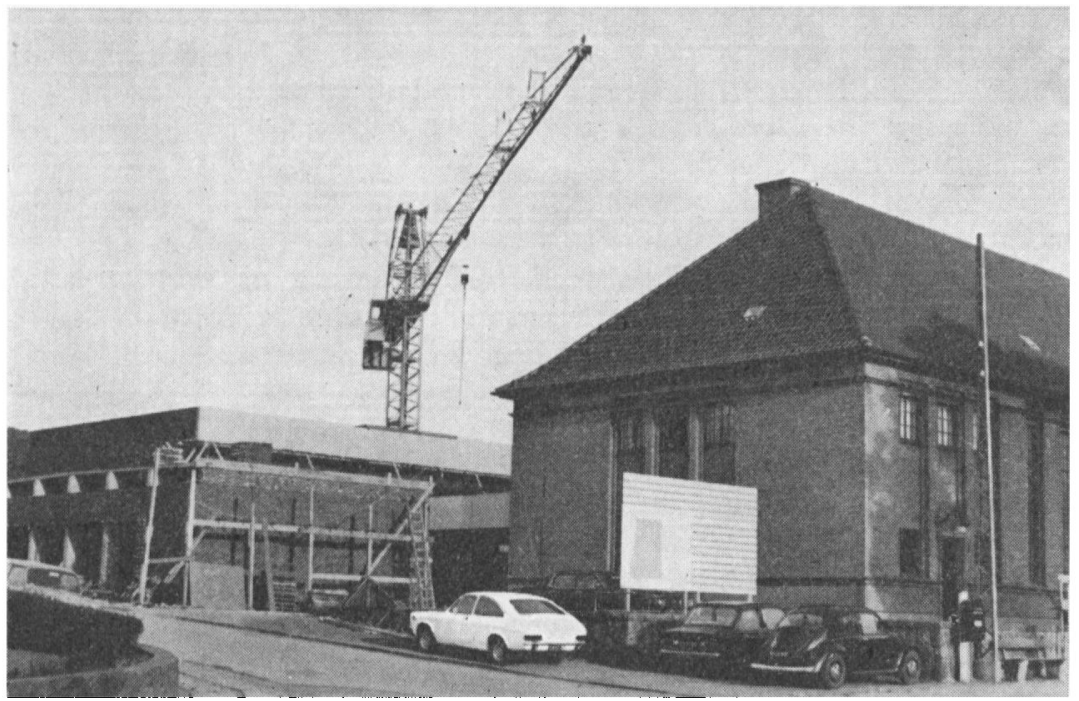

Landsarkivets nybyggeri set fra sydøst, oktober 1972. I forgrunden den gamle arkivbygning. (Foto: Dorrit Andersen).

Også $\mathrm{i}$ indeværende år har Landsarkivet måttet aftage nogle embedsarkivalier, nemlig en del sager fra det nu nedlagte Haderslev amt, medens sagerne fra det nedlagte Tønder amt, takket være velvilje fra Tønder kommunalbestyrelse, har kunnet forblive på deres plads $\mathrm{i}$ den tidligere amtsbygning, der nu er overtaget af Tonder kommune. Fra privat side har Landsarkivet bl. a. modtaget dele af privatarkiver for gårdejer og kolportør Mads Jensen, Jxgerup, d. 1909, og datteren fru Magdalene Moos, Nybøl, d. 1956, begge afleveret af rentier Svend Moos, Kollund. Der er kommet supplerende afleveringer til forstander Hans Lunds privatarkiv, og arvingerne har afleveret statskonsulent Johs. Jensens efterladte papirer, d. 1971. Af fru Bo Bojesen, Ảbenrå, er afleveret sogneprest Jørgen Eriksens, Asserballe, privatarkiv, dele af gårdejer Christen Hanssens, Nørremølle, privatarkiv og de Bojesen'ske familiearkiver. Jørgen Bromand har afleveret Ketting Andelskasses og Aksel Rahr Visby Husmandsforenings arkiver. Supplerende aflevering til Rødding højskoles arkiv er kommet fra friskolelærer Aksel Appel, Kerteminde, og fru Anne Marie Skau, Nygård, har suppleret Skrumsagernes familiearkiver. Søren Nissen, Harres, har afleveret Harres grandearkiv og amtsskolekonsulent Thygesen Tenderhus' arkiv 1919-68. Mejeriselskabet Danmark, Region Syd, har afleveret en rxkke sønderjyske andelsmejeriers arkiver, medens forretningsfører Michael Møller og frue, Christiansfeld, har afleveret Anderupgårds arkiv, indeholdende perga- 
menter tilbage til første halvdel af $1500^{\prime}$ årene. Hans Kxstel, Dybbølsned, har afleveret Sundeved frimenigheds arkiv, ligesom der er kommet værdifulde afleveringer og gaver fra Else Florander, Johan Thoms, Rise, Hans Brandt, Fåborg, direktør J. E. Christiansen, København, Anna Jasmund, Åbenrå, forstander N. J. Thïm, Tønder, Henrik Rasmussen, Ábenrå, Troels Fink, Flensborg, Misse Høier, Klovtoft, P. Michelsen, Vordingborg, Cathrine Reeses arvinger og Holger Skovmand, tidl. Løgumkloster. Sidst er kommet Ingeborg og Kr. Refslund Thomsens privatarkiver sammen med et værdifuldt supplement til håndbogssamlingen. Det er $\mathrm{i}$ høj grad en broget blanding af navne og afleveringer, som imidlertid giver et godt indtryk af, at man $i$ vide kredse $i$ landsdelen nærer stor interesse for Landsarkivet, og at man forstår betydningen af, at papirer, der ofte er klenodier for det enkelte familiemedlem, bedst kan bevares for efterslægten i Landsarkivet.

Af Landsarkivets ovrige aktiviteter kan nævnes, at arkivar Viggo Petersen igen sidste vinter har ledet et vejledende kursus for personalhistorisk interesserede, arrangeret af Historisk Samfund for Sønderjylland.

\section{P. K. I.}

\section{Historiske samlinger for SonderJylland.}

Arbejdet har ligesom forrige år hovedsagelig været koncentreret om indsamling og registrering af billeder. Antallet af indsamlede billeder og negativer har i 1971/72 været 2713 mod 3661 det foregående år, i tal altså en lille nedgang, men kvaliteten af de indsamlede og købte billeder er til gengald noget bedre. Historiske Samlinger har desvarre kun et beskedent årligt beløb til rådighed og må derfor $\mathrm{i}$ det hele og store txlle sin tilvækst blandt gaver fra velyndere. Kun $i$ begrænset omfang kan der tages kopier af lante negativer $i$ privat eje eller $i$ andre samlinger. Blandt glade givere kan blandt mange nævnes sognepræst Urban Schrøder, Varnæs, programsekretær Sigfred Jespersen, Abenrå, fru Catharina Reeses arvinger, Danmarks Radio, lærer J. Holdt, Rugbjerg, Dansk Jernbaneklub, fru Misse Høier, Klovtoft, fru Christine Bech, Ảbenrå, fru F. M. Döring, Ảbenrå, fru E. Bo Bojesen, Ảbenrå, statskonsulent Johs. Jensens arvinger, lektor Beck, Abenrå, cyklehandler Chr. Nissen, Hjerting, og Senius Tiedemann, Hovslund. I sommerens løb 1972 er ligeledes modtaget mange gaver, som vil blive medregnet i statistikken for 1972/73. Dette galder også de billeder, der er modtaget fra det udvalg, der under larer W. Leicks ledelse fotograferer gamle bygninger på landet i Tonder amt. De modtagne billeder er indordnet og registreret af fru Vibeke Gribsvad. Om Historiske Samlingers øvrige virksomhed 1971/72 henvises iøvrigt til Historisk Samfunds årsberetning, se side 223.

P. K. I. 


\section{Studieafdelingen ved Dansk Centralbibliotek for Sydslesvig.}

Der er ingen $æ$ ndringer sket $\mathrm{i}$ tilsynsrådets sammensætning siden sidste årsberetning.

Stipendiat, cand. mag. Gudmund Tybjerg blev 1. 8. 1971 ansat som adjunkt ved Tønder seminarium. Samme dato tiltrådte stipendiat, cand. phil. Anders Ture Lindstrøm, der studerer den politiske udvikling $i$ lander Slesvig-Holsten i tiden 1945-71. Redaktør Aksel Lassen, København, fik efter afgerelse i tilsynsrådet et stipendium til med særligt henblik på området syd for den dansk-tyske græense i perioden 1867-1920 at undersøge forbindelsen mellem befolkningsudvikling, vælgertal og stemmetal.

Der er under redaktion af bibliotekar Poul Kürstein udgivet to bøger i beretningsåret. Den første en oversættelse af tidligere indenrigsminister Hartwig Schlegelbergers "Der europäische Aufbruch» (1969) med titlen „Europa set fra den dansk-tyske grænse ". Bogen er oversat af vicekonsul Herluf Hansen, Flensborg, og den danske udgave rummer et opgør mellem dr. Schlegelberger og ledelsen af Det socialdemokratiske Parti i SlesvigHolsten, medlem af landdagen i Kiel, Joachim (Jochen) Steffen, dels i form af en brevveksling, dels en gengivelse af en dreftelse mellem de politiske modstandere $i$ den nordtyske radio, et opgør, der fandt sted i 1963. Poul Kürstein har skrevet forordet og en presentation af forfatterell samt udarbejdet noter og register.

Desuden blev tidligere skoleinspektør L. S. Ravns "Lxerne under sprogreskripterne 1851-64« udgivet. L. S. Ravns indsamling af biografiske data på 361 af de ca. 400 ansatte lærere i sprogreskripternes tosprogede områder afdækker et vigtigt historisk stof, og det af bibliotekslektoren grundigt udarbejdede note- og registerapparat øger udgivelsens værdi. Bogen er tilegnet tidligere vandrelærer Niels Kjems og hustru, Anna Kjems, Harreslev.

Samarbejdet med videnskabelige biblioteker og arkiver har som hidtil fungeret godt og kom især til udtryk under arbejdet med $*$ Larerne under sprogreskripterne«, hvor en livlig korrespondance og billedudveksling fandt sted mellem Det kgl. Biblioteks kort- og billedafdeling og Studieafdelingen.

Bibliotekslektoren har i beretningsåret fået endnu et manuskript færdigt, nemlig til bogen "Barn i Flensborg«, hvortil en rekke flensborgere har ydet væesentlige erindringsbidrag fra perioden 1890-1920.

Jørgen Hamre.

\section{Haderslev museum.}

Museets udgravningsvirksomhed startede i marts måned efter henvendelse fra gårdejer Jørgen Ditlevsen i Sommersted, der havde stødt på nogle store sten under forårspløjningen. Udgravningen afslørede, at stenene hidrørte fra randstenskredsen af en ikke tidligere registreret langdyss Dyssekamret var fjernet, idet der $i$ langdyssens midte fremkom en større 
nedgravning af nyere dato. Herefter udgravedes en overpløjet høj ved Raade hoved på gårdejer Iver Fallesens mark. Denne viste sig også at være en ødelagt langdysse, $i$ hvilken der havde varet to dyssekamre med kort gang. Udenfor dyssekamrenes indgange fremkom en mxngde rigt ornamenterede lerkarskår fra yngre stenalder, antagelig hidrørende fra lerkar, der i sin tid har veret henstillet ved dyssens randsten. Udover disse skår blev der fundet tre flintmejsler ved langdyssens sydvestside. Ca. 100 meter nordvest for den undersøgte langdysse ligger den kendte og på Haderslev næs bedst bevarede jættestue - Tonneshøj. Jættestuens kammer og gang blev udgravet i 1931, hvor der da blev fundet flere tyknakkede og tyndbladede flintøkser samt lerkar fra mellemneolitisk tids slutning, St. Valby-fasen. Uden for denne jxttestues indgang var der $\mathrm{i}$ foråret pløjet adskillige rigt ornamenterede lerkarskår frem, og efter vore erfaringer fra andre undersøgelser af lignende anlæg hidrørte disse skår antagelig fra lerkar, der har været henstillet ved randstenene med og som offer på begge sider af jættestuens indgang. Udgravningen viste, at dette var rigtigt, idet der fremkom et meget betydeligt skårmateriale, der er af stor videnskabelig betydning, eftersom det stammer fra jættestuens opførelsestidspunkt, d. v. s. fra mellemneolitisk tids begyndelse. På grund af, at Tonneshøj-jettestuen var tæet bevokset med slåen og større trxer, og da den vestlige del af randstenskredsen var meget beskadiget, blev højen restaureret ved samme lejlighed, og resultatet fremgår af hosstående fotografi. Udgravningen af den store tuegravplads ved Arupgård, der foretages i samarbejde med Statens Humanistiske Forskningsråd, blev fortsat $\mathrm{i}$ år, efter at museet havde foretaget en undersøgelse ved Draved af anleg fra historisk tid. Udgravningen ved Arupgård koncentrerer sig $i$ år om de tuegrave, der ligger $i$ heden nord for det ca. 12 tønder land store område, der blev undersøgt i 1970 og 1971. Undersøgelsen vil vare til hen $\mathrm{i}$ oktober måned; indtil nu har gravningen givet som resultat, at der rundt om tuerne har stået en rakke nedhamrede pale med 30-50 cms mellemrum. Pxlene har været omkring $10 \mathrm{~cm}$ tykke og er hamret henved $80 \mathrm{~cm}$ ned $\mathrm{i}$ undergrunden. Hvordan disse pxle skal tolkes, er det endnu for tidligt at udtale sig om.

I forste halvdel af året har museet modtaget mange gaver fra museets venner til den historiske afdeling; herudover har museet erhvervet et hovedvandsæg af Wolfgang Petersen, og på en mindeudstilling for kunstneren V. G. Kühnel erhvervede museet to malerier, foruden at museet modtog et billede, som V. G. Kühnel havde testamenteret til museet. I det forløbne halve år har der været tre kunstudstillinger på museet af henholdsvis Rasmus Nellemann, P. Brandes og C. E. Falbe Hansen, og ved årsskiftet afholdt Haderslev byhistoriske arkiv en udstilling $i$ anledning af sit 25 års jubilaxum, hvor der vistes et udvalg af billeder og dokumenter om byen og dens borgere. Også i år har museet arrangeret en forelæsningsrække under folkeuniversitetet, og også denne gang måtte forelæxsningerne holdes i lokaler udenfor museet, da museets sal ikke kunne rumme de mange 


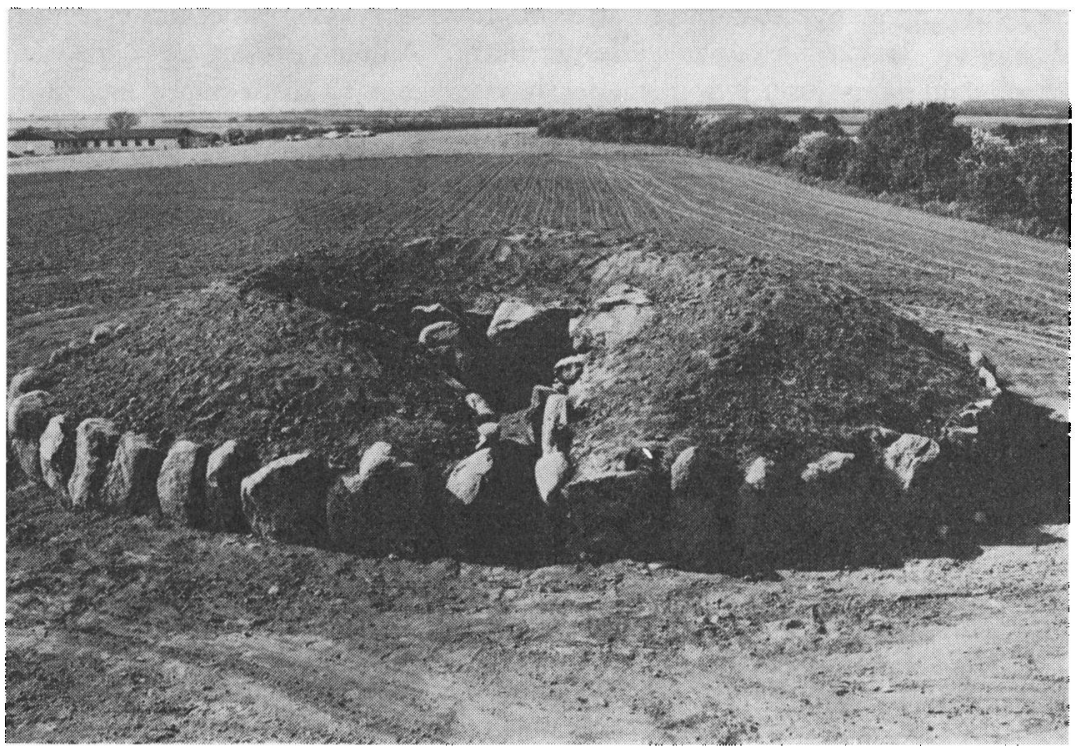

Tonneshoj-jettestuen ved Rådehoved. Efter udgravninger og restaurering 1972. (Haderslev museum).

deltagere. Forelæsningsrækken omhandlede hovedsagelig problemer indenfor bronzealderen. Universitetslektor, mag. art. Ebbe Lomborg talte om: Bronzealderens komme, universitetsprofessor, dr. phil. C. J. Becker behandlede: Bronzealderens boligproblem, museumsinspektør, mag. art. Henrik Thrane tog sig af: Handelsforbindelser i bronzealderen, mens universitetsamanuensis, mag. art. Jørgen Jensen forelæste om: Bronzealderens småbilledkunst, og sidst talte museumspxdagog, mag. art. Erik Jørgensen om: Jernalderens opdagelse i Danmark og Sønderjyllands tidlige jernalder.

Museets årsskrift indeholder foruden årsberetningen af Hans Neumann følgende artikler: Søren H. Andersen: En skafttungepil fra Årupgård, Erik Jørgensen: Et bidrag til diskussionen om tidspunktet for enkeltgravskulturens indvandring, Erik Jørgensen: Tuegravpladsen ved Årupgård, II, Jens Larsen Jacobsen: Det var kattens, Knud A. Larsen: Guldhornsbilleder af Odin, A. C. Henningsen: Et minde fra første verdenskrig og Senius Tiedemann: Levn fra overtroens tid.

I årets første halvdel er der bl. a. foretaget omflytning af museets kontorer, der tidligere var rum, der var skilt fra den store udstillingssal. $\mathrm{Nu}$ er museumsbetjentens tjenestebolig taget ind som kontorer og den store udstillingssal ført tilbage til sin oprindelige størrelse. Herefter skulle museet have mulighed for at arrangere større udstillinger, og universitets- 
forelæsningerne og andre foredrag vil atter kunne holdes $\mathrm{i}$ museets egne lokaler.

Fra 1. august er Hans Rathje tiltrådt som teknisk tegner ved museet.

E. J.

\section{Abenrả museum.}

Besøget på Ảbenrå museum har atter været $\mathrm{i}$ en stat fremgang. I 1971 havde man 15.712 gxster mod 13.268 i 1970.

Af udstillinger har man haft folgende:

Ulandsudstilling arrangeret af $\gg$ Terres des hommes«.

Fotoudstilling: »Sønderjylland mellem 1864-1920 « i forbindelse dermed fremvisning af gamle film fra genforeningen 1920 i Ảbenrå og Haderslev.

Fra den 16. 12. til 31. 12 1971: Det traditionelle »Oldemors juletræ«, der samler mange børn og forældre, der danser om det hver eftermiddag.

Udstillingen "violet sol « malerier af Ole Prip Hansen, Niels Reumert. Willy Birckner og Bjarne Esbensen.

8. 3. til 9. 4. 1972 udstilling af grekkebreve, klippede af skolebørn fra Ảbenrå og omegn. Denne udstilling var sxrdeles velbesøgt og var senere udlånt til Ribe. 17. 3. til 9. 4. havde man også en udstilling af håndarbejder, udført af Jomfru Fanny, og genstande, der havde tilhørt hende, en arv efter fru Henriette Have, født Junggreen. I samme tidsrum havde man en mindeudstilling for Abenrå-maleren Johann Petersen Ebbesen. Den 15. 4. til 30. 4. en fotoudstilling af den unge fotograf Niels Jørgen Madsen, Ảbenrå. Den 1. 7. til 15. 7. 1972 udstiling af håndkolorerede kobberstik i faksimile, fremstillet $\mathrm{i}$ Wien, og endelig den 4. 8. til 4. 9. 1972 udstilling fra Carl Gruvemanns samling af dansk kunst fra 4050-tallet, nemlig Axel Bentzen, Jens Søndergaard og Hans Øllgaard.

Af større gaver har man faet en buste fremstillet af Nikolaus Wehding. Busten forestiller kunstnerens far, orgelbygger Adolf Wehding, Ảbenrå, Skibsbilledsamlingen er blevet forøget med to meget fine skibsbilleder, nemlig af briggen "Jupiter" og fregatten "Catharina*, sidstnæunte er malet af Bøttger, Altona. Disse billeder er skænket af fru Helene Bune, Ảbenrå. Samlingen af Ảbenrå-sølv er yderligere blevet kompletteret ved køb og gaver.

H.J.

\section{Museet pả Sønderborg slot.}

I foråret 1971 havde museet åbnet to udstillinger, en søfartsudstilling $i$ anledning af Sønderborg Skipperlaugs 400-års jubilæum og en udstilling, der fortalte om Sønderborg slots bygningshistorie. Begge udstillinger bidrog til at øge museets besøg, der nåede endda lidt højere end de 56000 i 1970 - 50-året for genforeningen.

I 1972 kunne udstillingsarealet kun forøges med et enkelt værelse, idet 
restaureringsarbejderne fortsat koncentreredes om vestfløjen. Den bygningshistoriske udstilling blev så flyttet til et enkelt værelse $i$ sydfløjens stueetage, og derved blev to rum og et lille forrum på 2. sal ledige til en kulturhistorisk udstilling. Ved hjælp af malede møbler og døre, keramik, kniplinger og tylsbroderier $\mathrm{m}$. v. søgte museet her at anskueliggøre nogle af de egnsforskelle, der er indenfor det sønderjyske område. Disse interne grænser blev yderligere understreget ved en række kort- og billedplancher over jordbundsforhold, historiske granser, sprog, stednavne, byggeskik og håndværk. Til udstillingen låntes enkelte ting fra museerne i $\mathrm{Ha}$ derslev og Åbenrå.

Årsagen til, at museet valgte netop denne udstilling, var, at det 19 . nordiske etnolog- og folkemindeforskermøde skulle finde sted i Sønderborg den 22.-26. august, og at mødets hovedemne var grænser, især kulturgrænser. $\ddot{i}$ den anledning fik museet lov til $i$ august og september at låne en spæendende samling modeller med surdejsmærker og kageforme hos overbetjent Knud Jensen, Padborg, resultatet af årelang flittig forskning. Kongressens deltagere fik da også lejlighed til at se både denne og museets øvrige udstillinger. I forbindelse med et samlet besøg var museet vært ved en reception, hvor der blev talt af førstekonservator Olav Bøe, Norge, og museets formand, fru Christa Knudsen. Traktementet, der vakte stor begejstring hos de nordiske gæster, var solæg, Bommerlunder og øl.

Kongressen gav også på anden måde arbejde for museet, idet alle måltider var tilrettelagt i nært samarbejde med Idrætshøjskolens økonoma, fru J. Hansen, og museumspæedagog fru I. Adriansen. Ved middagen blev gasterne bl. a. budt på snysk, suramsuppe, sønderjyske frikadeller, fersk suppe og to slags steg, og desuden fik de bl. a. smagt surrib og ringriderpølser. Iøvrigt havde museumsinspektøren været inddraget $i$ kongressens tilrettelæggelse, og han deltog sammen med museumspædagogen som »busfører « ved udflugterne. Museet har endvidere ved Idratshøjskolens elevmøde medvirket ved arrangementet af en sportsudstilling. Dele heraf vistes senere på biblioteket. Museet har sammen med Forhistorisk Museum, Århus, foranstaltet en udgravning på Brovold under ledelse af stud. mag. Jan Kock. I 1971 gravedes to mindre prøvegrøfter for at skaffe kontakt med Jens Rabens gravninger fra 1930-32, og i 1972 gravedes dels et firkantet felt med en stor grube, dels et snit gennem vold og voldgrav. Det var første gang, der blev foretaget et voldsnit, og det lykkedes at fastslå opbygningen med græstørvsforstærkede sider helt tydeligt. I det hele taget afgav de to års gravninger godt materiale til en nøjere datering af Brovold. Samtidig har museet sikret sig konservering også af de tidligere fundne genstande.

Samlingerne er forøget både ved gaver og køb. Til krigsmindesamlingerne drejer det sig først og fremmest om et par hele uniformer samt en hel rakke uniformsjakker. Desuden hjelme, bælter, udmærkelsestegn og distinktioner og en del andet tilbehør, foruden adskillige billeder. Til den kulturhistoriske afdeling er indgået en samling duge, lagener, hovedtøjer og andre tekstiler. Møntsamlingen er forøget med flere kostbare indkøb, bl. a. en 
sjælden, såkaldt Albertus-thaler fra 1753, en Chr. V's 4 mark fra 1693, en dødsdaler fra Frederik II's datter Elisabeth fra 1626 og en speciedaler fra 1795. Endelig har Ny Carlsberg-fondet skænket 3 malerier af W. Birckner, og til kunstafdelingen er købt en tegning af Johs. Carstensen og to malerier af C. A. Lorentzen. Som testamentarisk gave har museet modtaget et maleri af V. G. Kühnel.

Som nævnt deltog fra museet i den nordiske etnologkongres i Sønderborg både museumsinspektøren og museumspredagogen.

I DKM’s kursus på Brandbjerg højskole deltog 3 fra museet, inspektør, predagog og tekstilkonservator. Desuden har fru I. Adriansen deltaget i DKM's arbejdsmøde på Lakolk, og J. Slettebo repræsenterede museet på DKM's årsmøde i Halmstad i september 1972. Sidstnævnte er blevet indvalgt $\mathrm{i}$ bestyrelsen for Dansk Historisk Fxllesforening og har som vanligt deltaget $\mathrm{i}$ møderne $\mathrm{i}$ boligministeriets byggeudvalg vedrørende Sønderborg slot.

J.S.

\section{Tonder museum.}

Siden 1960 har det $\mathrm{i}$ museets årlige beretning $\mathrm{i}$ Noter og nyt vxret et stående tema at henvise til bygge- og udvidelsesplaner. 23. juni 1972 åbnedes Sønderjyllands kunstmuseum $\mathrm{i}$ arkitekterne Peter Koch og Nils Rode Møllers nye bygning og samtidig det nyrestaurerede og udvidede Tønder museum, og dermed er en plan, som tog form allerede $i$ slutningen af 1930'erne, bragt til lykkelig gennemførelse, og Sønderjylland er blevet beriget med et kulturhus af en kvalitet af landets bedste.

Museet grundlagdes i 1923 som et kombineret kulturhistorisk og kunstmuseum. Allerede for udbruddet af 1 . verdenskrig planede man et museum $\mathrm{i}$ byen, men forst efter genforeningen lykkedes det $\mathrm{i}$ forbindelse med Hercules von Oberbergs noget misrogtede porthus til slottet at rejse en efter tidens forhold imponerende museumsbygning, opført af den habile Tønder-arkitekt Lauritz Thaysen. Den anbragtes parallelt med porthuset $i$ retning øst/vest $i$ en læangde af ca. $29 \mathrm{~m}$, og således at den oprindelige port anvendtes som indgang $i$ et harmonisk langhus med en ny påsat frontspids $i$ egnens bygningsstil. Med en betagende pergola og et dertil knyttet »borgtårn « forbandtes den nye fløj med porthuset, hvorved der skabtes et af alle beundret gårdinteriør, som forlenede anlægget med en rørende slotsatmosfære. - Bygningen var $i$ to etager med hhv. 4 og 3 ret store udstillingsrum, de sidste forbeholdt kunstsamlingen. Udstillingsarealet var ca. $400 \mathrm{~m}^{2}$ i den nye del, hvortil kom fængslerne og drabantsalen fra den gamle med knap $100 \mathrm{~m}^{2}$.

Thaysens bygning er stadig en fremragende museumsbygning, rummene er velproportionerede og $\mathrm{i}$ enhver henseende anvendelige til formålet. En skavank var det imidlertid, at der i 1923 ikke var penge til at restaure porthuset, som, efter at det i 1917 var ophørt at være byfængsel, havde fungeret som husvildebolig, og kun selve drabantsalen kunne nød- 
tørftigt gøres i stand; den fik en uheldig anvendelse ved at blive drekket med bastante træmontrer, de sidste 20 år rummende museets sølvsamling. De imponerende renæssancefængsler i stueetagen, delvis kasematanlxg for slottet, var der ingen adgang til, og de anvendtes en årrakke som museets magasin, og værst var det, at den smukke drabantsal ikke indgik $i$ rundgangen $i$ museet. I 1948 foretoges en større sanering, hvor bl. a. fængslerne ryddedes, og det store rum over porten frigjordes til en bemalet Rømø-stue og malede bondemøbler, men først med Peter Kochs og Rode Møllers tilbygning 1972 fik hele bygningskomplekset mening, idet de genialt flyttede hovedindgangen bag pergolaen $i$ vest, således at museumsrundgangen ledes gennem fængslerne og drabantsalen, og over porten til 1923-bygningen. Den nye nxsten $46 \mathrm{~m}$ lange museumsbygning er anbragt $\mathrm{i}$ retning syd/nord og tværs på Thaysens bygning. I forhold til porthusets kasematdel fremkommer der herved en ny sluseformet gård, beregnet for kunstmuseets kommende skulpturer, og den thaysenske galleribygning er blevet forlænget med en mellembygning i 2 etager, som forbinder nyt og gammelt, og forneden er vestibule for de 2 museumsafdelinger; i denne vestibule er opsat 2000 hollandske vægfliser fra tiden mellem 1750 og 1850, en imponerende introduktion ved hjelp af hidtidig magasinerede fliser. Herfra udgår så rundgangen i Tønder museum, først gennem pergolaen, som er lukket til med buevinduer, til de gamle fængsler, hvor der $i$ tre rum er gjort plads til tegninger, opmålinger og fund fra slottene Tonderhus, Trøjborg og Grøngård. Vi skylder lærer Leick tak for dette initiativ, og han har specielt stået for indretning af Grøngård-rummet, som vi håber at få suppleret med flere ting fra Nationalmuseet.

Med uvurderlig støtte fra arkitekt $H$. $H$. Engquist er drabantsalen ført tilbage til $\sin$ oprindelige skikkelse. Den falske dør $i$ sydvæggen er muret til, og den flotte kamin er rekonstrueret. En dejlig sandstenskamin fra Trøjborg (også opført af Oberberg), som havde ført en hensygnende tilværelse $i$ museets magasin, kunne omsider udstilles, og det til vagtstuen hørende shundehul $\ll$ førtes tilbage til sin oprindelige form. I porthusets sydvæg fandt man den oprindelige kurvehankbuede indgang til bygningen, og den frigjordes (dygtigt arbejde af murer Jessen), ligesom man $i$ porten udhuggede to af de oprindelige 18 stolenicher for vagtposterne på slottet (i den ene var træbænken intakt!). Porten kunne nu blokeres og anvendes som udstillingsrum med anbringelse af en af museets store attraktioner, kagmandsfiguren fra 1699, og af de smukke sandstensløver fra Trøjborg.

Først nu kommer man ind $\mathrm{i}$ det oprindelige museum, hvis 4 rum stort set er uxendrede, men grundigt istandsatte. I det inderste rums vestvxg, hvor der skulle foretages et gennembrud til den nye museumsbygning, er indsat en Louis XVI-dør fra det angelske hus (tidligere Tønder Landmandsbank) i Vestergade. Her stod oprindelig museets tre pragtskabe fra Bjerremark (opr. borgmester Carstens Richtsens), og det var en 
katastrofe, om denne væg skulle ødelægges med en moderne dør. Opgaven er løst nu ved anbringelse af døren $i$ et vindfang, og hvilken dør. Den flankeres af de to formentlig Altona-vitriner, og dens kedsommelige okkerfarve fra 1800 erne er fjernet og erstattet med den oprindelige bundfarve og rig guldstaffering. Igen et lykkeligt fund i museets righoldige magasiner.

Gennem denne dør kommer man ind i det nyindrettede sølvkammer, en Aladdin-hule, hvor museets sølvsamling er udstillet af fru Anne-Lise Rand på en helt uortodoks måde. Ikke mindre end 17 store montrer er helt fyldt op med landets righoldigste samling af lokalt sølv.

Af den nye bygning har Tonder museum yderligere overtaget to rum mere, et til keramik og et til topografi. Takket være storstilede tilskud fra A. P. Møllers fond fik museet mulighed for at anskaffe ikke mindre end 26 System abstracta-montrer af høj kvalitet. De anvendes foruden til slotsfundene $i$ fængselsrummene, $i$ keramikrummet, $i$ hovedtrappen med kirkelige sager, $i$ den ene sal på 1. etage, hvor museet endelig har kunnet få sine kniplinger udstillet, og $i$ den tidligere store kunstsal, hvor der er udstillet folkekunst, herunder også museets omfattende samling af malede skabe fra 1700-tallet.

I beretningsperioden er erhvervet tre store skabe, et fra $\varnothing$. Gammelby (uden overmaling), et fra Rejsby/Ballum, som er afdakket, og et fra Nibøl-området med allegoriske fremstillinger af de 4 årstider.

I det tredje af de oprindelige kunstrum er udstillet tekstiler (også noget nyt) og $i$ en restaureret karnap fra Spikergade 17 (omdannet til vitrine) en rig samling af jydepottearbejder.

Mens rundgangen $i$ stueetagen er blevet perfekt, kan det tilsvarende i 1. etage først gennemføres, når kustodeboligen er nedlagt. Det forventes gennemført i nærmeste fremtid. Så vil man fra Rømø-stuen over porten kunne fortsætte gennem byfængslerne på 1. sal.

Det samlede udstillingsareal $\mathrm{i}$ huset var før nybygningen ca. $350 \mathrm{~m}^{2}$. $\mathrm{Nu}$ er det på $669 \mathrm{~m}^{2}$, hvortil kommer magasiner med $240 \mathrm{~m}^{2}$, værksteder med 74 og kontorer med $35 \mathrm{~m}^{2}$. Det samlede indendørsareal for Tønder museum er $1036 \mathrm{~m}^{2}$. - Til gengæld er lejemålet af Allégade 15, hvor vi før havde magasiner, ophørt.

I tiden mellem 1. november 1971 og 23 . juni måtte museet lukkes på grund af restaureringen. Besøgstallet den første måned efter åbningen var på ca. 3000.

I april 1972 trådte den nye bestyrelse for museet $\mathrm{i}$ funktion efter et interregnum på 2 år. Formand er amtsrådsmedlem, lærer Edgar Andersen, Visby, næstformand byrådsmedlem, overlærer Olav Knudsen, Tønder,

Museets 1. særudstilling var en udstilling fra frisisk museum i Leeuwarden i tiden mellem 25. juni og 20. juli.

S. Sch. 


\section{Restaureringen af Sonderborg slot.}

På Sønderborg slot er restaureringsarbejderne fortsat efter planen. Arbejdet har $\mathrm{i}$ det forløbne år været koncentreret $\mathrm{i}$ vestfløjen, hvor man som $i$ de tre andre fløje for længst har fornyet vinduerne og nu er $i$ fard med udskiftning af gulve og indlægning af varme og elektricitet. I stueetagens sydlige ende er der bevaret så store dele af slottets oprindelige store skorsten med åbent ildsted, at man har besluttet at bygge det kommende cafeteria op omkring dette. Kokkenet bliver kun lille, og en egentlig restauration bliver der ikke tale om. Det næsten kvadratiske ildstedsområde med svære murede buer imod tre sider er imidlertid genskabt, og omkring dette bliver der plads til borde og stole til 60-80 mennesker. Særlig smukt bliver det lange tøndehvælvede rum mellem ildstedet og drabantsalen. På forste og anden sal bliver den store skorsten ikke genskabt, men kun markeret ved de spor, der er bevaret i murværket. Her er flere mindre rum med bindingsvarksvægge, der kommer til at give en behagelig afveksling fra museets øvrige, ret store rum.

I gården er den gamle, for længst ødelagte brolægning afgravet, og derved er også den forhøjning i gårdens midte, der stammede fra 1914, taget væk. I stedet lagges nu en brolægning, der hxlder svagt fra sydfløj til nordfløj, således som de xldre brolægninger har gjort. Ganglinierne markeres ved brede granitsten, det øvrige belægges med gammeldags, toppede sten. Samtidig lagges en $2 \mathrm{~m}$ bred brostenskant langs alle slottets ydermure.

I det nordvestre hjørne fortsattes arbejdet $\mathrm{i}$ de rum, hvor man sidste år fandt resterne af et loft fra Chr. III's tid. Dette loft genskabes, og der bliver nogle meget fine rum, hvoraf et par er beregnet til at rumme museets undervisningslokaler. Under arbejdet med istandsxttelse af en bindingsværksvæg fandt man her rester af en ellers for længst forsvundet indskrift, bestående af nogle årstal fra 1500-tallet og et par mandsnavne, velsagtens på håndværkere eller måske præster eller hoffolk. Nogen sikker forklaring er ikke fundet, da ingen af navnene er identificerede. $\mathrm{Da}$ det kun er brudstykker, er det vel også tvivlsomt, om det nogensinde sker. Restaureringsarbejdet forventes fuldfort i 1973.

J.S.

\section{Kunstmuseet »Holmenu, Løgumkloster.}

Kunstmuseet $»$ Holmen «, Løgumkloster, indledte den anden sæson $\mathrm{Kr}$. Himmelfartsdag med en nyophæengning af Olivia Holm-Møllers arbejder.

Ligesom den første ophængning tilstræber denne ophængning at vise Olivia Holm-Møllers udvikling fra billedhugger til maler - fra de første naturalistiske arbejder til de rent abstrakte - og den viser hendes alsidighed $\mathrm{i}$ udtryksformer. O. H.-M. var lige stor, om hun stobte $\mathrm{i}$ gibs eller bronce, om hun skar $\mathrm{i}$ træ, ridsede $\mathrm{i}$ zink, tegnede, malede akvareller med lette strøg eller malede de store farvemættede lærreder.

Fra den første udstilling er bibeholdt nogle af hendes hovedværker: Jonas-serien, et motiv, der optog hende meget, og som hun har udført 
både $\mathrm{i}$ akvarel og $\mathrm{i}$ træsnit. Museet ejer dog kun træsnittene. Desuden Eva-billederne: »Den unge Eva « og "Den gamle Eva«, begge malet $i$ 1941, og "Den ny slægt «, der er nr. 6 i serien "Slægten «, malet $\mathrm{i}$ årene 1934-47.

Museets åbningstider er: juli og august, kl. 10-12 og 14-17. Resten af året kl. 15-17; mandag lukket hele året.

E. $K$.

\section{Den store egnsvandring 1972.}

Lørdag den 9. og søndag den 10. september stod i alt omtrent 350 medlemmer af Historisk Samfund tidligt op for at "vandre . Egnsvandringsudvalget - viceskoleinspektør Chr. Stenz, museumsdirektør Sig. Schoubye og direktør Hugo Lildholdt havde med kontorassistent Erland Møller som chauffor grundigt undersegt mulighederne for at sammensæette et program om Ditmarsken. Kun én eneste ting blev ikke ordnet: Mens udvalget sørgede for det traditionelle gode vejr om lordagen, glemte man ganske at sikre søndagsdeltagerne solskin. Men regnen gjorde nu ikke skår $\mathrm{i}$ fornøjelsen.

De to ture lignede hinanden meget. Lørdagsturen gik efter programmet, bortset fra, at man ekstra fik en velkomst af borgmesteren $i$ Heide. Til gengæld fik søndagsgæsterne programmet baglæns, idet man af hensyn til formiddagens gudstjenester måtte vente med kirkebesøgene.

De 170 søndagsdeltagere begyndte altså i Saksergården i Meldorf, der meget bekvemt lå lige bag et kaffe-Holländerei. Besøget her var ikke sarlig organiseret, men den faste opsynsmand gjorde, hvad han kunne, for at delagtiggøre alle $i$ sin viden. Bygningen var et eksempel på de kollossale, store gårde, der ikke mere eksisterer, og overblikket besværliggjordes yderligere lidt af, at vi var så mange derinde på én gang; men der var mange enkeltheder at kigge på, og man må forbavses over den tillid, der blev vist de besøgende, for utallige småting stod frit fremme.

Derefter gik et hold på byvandring med museumsdirektør, Dr. N. R. Nissen som cicerone i Meldorfs gader, og turen sluttede på det berømte væveri, hvor man nok dyrker de gamle mønstre, men samtidig søger fornyelse gennem moderne kunstneriske inspirationer. Adskillige forsynede sig her med håndfaste minder om turen.

Fra væveriet gik man til Ditmarscher Landesmuseum, hvor dr. Schoubye med tålmodighed modtog alle interesserede og beredvilligt gentog sit foredrag om museets skatte. Det andet hold gik den modsatte tur.

Til slut samledes alle i domkirken, den største midde!alderkirke på den slesvig-holstenske vestkyst, den utroligt store, treskibede, gotiske kirke, som blev bygget af et lille landsbysamfund omkring 1300. Kirken blev gennemgribende restaureret $i$ slutningen af forrige århundrede. Dr. Nissen udpegede og kommenterede kyndigt de mange enkeltheder lige fra de ejendommelige kuplede hvælvinger til det rigt udskårne korgitter med apostelskikkelserne. 
Der gik om søndagen rygter om, at lordagens egnsvandrere delvis forvildede sig ind på det marked, der netop fandt sted uden for kirken, men rygterne mentes ikke at være troværdige. Og der var ikke marked om søndagen, så vi blev ikke fristet.

Middagen blev indtaget i Heide (der var en del, der havde medbragt mad), og da alle var mætte, fortalte Dr. Nissen om $»$ Bonderepublikken Ditmarsken « - turudvalget havde sørget for en oversættelse på forhånd, et særtryk af Sønderjysk Månedsskrift.

$P a ̊$ grund af søndagsregnen holdt Chr. Stenz sit »Dusenddüwelswarf «foredrag $i$ salen i stedet for ude ved monumentet for slaget ved Hemmingstedt den 17. februar 1500 , hvor 6000 ditmarskerbønder slog den danske konges og det slesvig-holstenske ridderskabs dobbelt så store hær, en sejr, der sikrede bøndernes frihed en årrække fremover. Et slagpanorama var iøvrigt opstillet i museet i Meldorf.

Man kørte forbi monumentet på vejen til Wesselburen, hvis kirke regnes for at være en af senbarokkens hovedværker. Den ejendommelige, kvadratiske grundplan giver den besøgende fornemmelsen af et meget stort kirkerum, og den særegne, tøndeformede hvælving over alteret danner sammen med de højtsiddende, vinkelbyggede loger for de bedrestillede familier et teaterlignende interiør, et indtryk, der forstarkes af inventarets farver, logernes blå, orgelsidens dybrøde og hvælvingens stjernebestrøede mørkeblå mod gulvets kølige grå bænkerækker. Direktør Sig. Schoubye fortalte om kirken, der blev ny-indviet i 1738, om logkuplen, som tårnet blev udstyret med som en elskvardighed overfor hertug Karl Frederiks gemalinde Anna Petrovna, Peter den Stores datter. Han fortalte om kirkens inventar og om dens historie.

En del havde energi til uden for programmet at besage Hebbelmuseet, en lille tur, der lønnede sig. Håndskriftsamlingen anses for museets kostbareste eje, de mange førsteudgaver $i$ montrene gjorde også indtryk, men tid til at fordybe sig $\mathrm{i}$ enkeltheder var der ikke. Derfor blev det nok digterens mere end spartansk moblerede kontor - han var ansat hos byfogeden fra 1827-35 som skriver og boede hos denne - der gjorde indtryk. Og uforglemmeligt var digterens prunkløse soveværelse, en alkove i baggangen bygget ind under trappen til førstesalen.

Turen til Ditmarsken fortalte om et lille bondesamfund, der isoleret bag floder og hav formåede at hævde sig, at opføre disse vældige kirker, der er et markant udtryk for det økonomiske grundlag, man også så genskær af på museet. Et isoleret folk i modsætning til de nordlige naboer, friserne, der gennem skibsfarten erhvervede et mere internationalt udsyn.

Sig. Schoubye ville gerne have haft et besog i Marne - det fjerde kulturelle center $i$ landet - med $i$ den omhyggeligt tilrettelagte tur for at afrunde indtrykket af Ditmarsken, men den sydlige del måtte gemmes. Der var også rigeligt endda til menigmand.

ibs. 


\section{Amtskredsenes arbejde}

\section{Haderslev amtskreds.}

Ved generalforsamlingen den 16. oktober 1971, der holdtes i Haderslev, bad pastor Tage Holm om at blive fritaget for hvervet som formand. I 15 år har pastor Holm varet det samlende midtpunkt $\mathrm{i}$ arbejdet $\mathrm{i} \mathrm{Ha}$ derslev amt, og de fleste forslag og idéer er udgået fra ham, ligesom arbejdet med deres gennemførelse blev gjort af ham. Medvirkende til pastor Holms beslutning har utvivlsomt været, at embedspligterne ofte kom $i$ vejen for arbejdet i Historisk Samfund. Der skal her lyde en tak til pastor Holm for den tid, han var formand. Det var ikke uden beklemthed, at arbejdet skulle tages op efter ham.

Den 19. april 1972 holdtes der møde og generalforsamling i Oster Lindet. En time forinden var der åbent hus på Nygård hos Anne Marie og Jens Skau. Det store hus på den forhenvxrende domænegård danner en fortrinlig ramme om alle de oldsager, møbler, gamle kister og vævede txpper, der her er samlet. Samtidig kunne medlemmerne besøge Johannes Søebergs have, $\mathrm{i}$ hvilken virkningen af blomster og plantningerne er udnyttet med en sjælden sans for det skønne og kunstneriske.

Den 13. juli blev årets gravfund vist for alle interesserede på gravpladsen $\mathrm{i}$ Årup. Frk. Ulla Rasmussen fortalte levende om de hidtil nåede resultater og de sidst fundne ting. Her var mødt ca. 60-70.

I Hygum forsamlingshus var der kaffebord. Her fortalte Harald Johannsen og Hans Fredslund om arbejdet med Hygum sogns historie.

Til slut var der lejlighed til at se det nyindrettede arkiv og museum i det tidligere kommunekontor, hvor alt opbevares under sxrdeles gode forhold. Egnsvandringen fastsattes til at skulle foregå på Haderslev Næes den 13. august.

Der er $\mathrm{i}$ det forløbne år knyttet syv nye tillidsmænd til vort arbejde.

K. $H$.

\section{Abenrá amiskreds.}

Tirsdag den 2. maj 1972 holdt Ābenrå amtskreds sin årlige generalforsamling. Efter at beretning og regnskab var godkendt, genvalgtes pastor Urban Schrøder til bestyrelsen. Han holdt, efter at generalforsamlingen var overstået, et usædvanligt fængslende foredrag om den ukendte unge salmedigter J. Gadeberg fra Nørre Hostrup. Pastor Urban Schrøder indledte sit foredrag med undskyldende at bemærke, at emnet jo var så specielt og derfor måske noget kedeligt, men bifaldet fra de mange fremmødte gjorde denne antagelse til skamme. Foredragsholderen fortalte både om den unge digters korte liv, han døde af »tæring * kun lige tyve år gammel, og om hans salmers kvalitet, idet han analyserede flere af dem og påpegede, hvilken påvirkning der havde ligget til grund for dem. 
Onsdag den 17. maj 1972 forsøgte man at opfylde løftet om en byvandring i Abenrå. Vejrguderne var ikke venlig stemt mod arrangementet, idet det øsregnede og var koldt og blesende som en barsk vinterdag. Man regnede med en aflysning, men der mødte så mange, at man dårlig nok kunne være flere. Leder af turen var arkivar, cand. mag. Viggo Petersen, Ảbenrå, der er særdeles velkvalificeret, idet han af Ảbenrå kommune er sat til at udarbejde en bevaringsplan for Abenrå sammen med arkitekt H. H. Engquist, København, en af landets fineste specialister på området. Rundturen sluttede $\mathrm{i}$ fru dr. Beyers smukke have ved den arkitektonisk fine ejendom $\mathrm{i}$ Søndergade. Turen blev trods vejret en sådan succes, at man måtte love at fortsætte med disse byvandringer.

Søndag den 11. august 1972 arrangerede man en udflugt til museet $i$ Froslev og til Frøslev polde. Denne udflugt foretoges $\mathrm{i}$ forbindelse med Folkeligt Samfund i Ảbenrå.

H.J.

\section{Sonderborg amtskreds.}

Den 17. november 1971 holdtes efterårsmøde på Nørherredhus.

Gårdejer Olav Bonefeld, Snogbak, holdt et interessant lysbilledforedrag om danske minder i Sydindien. Han gav først en historisk oversigt over den periode, da Trankebar var dansk (1616-1845). Derefter fortalte han om sine indtryk fra sine rejser til Trankebar og Sydindien. Han berettede meget levende om de to gamle kirker fra den danske periode og om den gamle kirkegård med alle dens historiske minder og om Dansborgfortet. Fra den ene af kirkerne, Zionskirken, viste han nogle billeder af kirkesølv, bl. a. en meget smuk alterkalk og et dåbsfad. Desuden havde han aflagt besøg $i$ museerne $i$ Madras, hvor der findes en stor samling af de gamle mønter. Bonefeld har som bekendt selv en fin samling af de gamle Trankebarmønter. Han havde medbragt nogle, som han viste forsamlingen.

Det var en meget vellykket aften med stor deltagelse, ca. 60.

Den ordinxre generalforsamling holdtes den 20. juni i Broager pá Jes Jacobsens hotel. Inden generalforsamlingen mødtes vi i Broager kirke, hvor pastor Vestergård fortalte om Broager kirke og bagefter viste os rundt på kirkegården.

Ved kaffebordet bagefter $p a ̊$ hotellet besvarede pastor Vestergård spørgsmål fra deltagerne. Generalforsamlingen afvikledes hurtigt, beretning og regnskab godkendtes. Bestyrelsen genvalgtes.

D. K. H.

\section{Tonder amtskreds.}

Den 26. 1. 72 holdt amtskredsen et vintermøde på Landbohjemmet $i$ Skærbæk, hvor rektor D. Keller Hansen, Sønderborg, indledningsvis fortalte om Köller-politikken og Skærbækpræsten Jacobsens mere eller mindre 
mislykkede foretagende $\mathrm{i}$ fortyskningens tjeneste for en lydhør forsamling på over 100. Efter kaffebordet blev tingene nærmere uddybet af flere af mødedeltagerne, ligesom der blev fremdraget minder fra den tid.

Den 23. 3. 72 var amtskredsen medindbyder til et møde i Emmerlev forsamlingshus i rækken af Højeregnens aftenhøjskoleforedrag. Iørn Piø fortalte om Emmerlev-undersøgelserne. Der var ca. 75 deltagere, hvilket var det dobbelte af tilslutningen ved de andre møder $\mathrm{i}$ aftenhøjskolen.

Den 11. 4. 72 holdtes årsmøde og generalforsamling på Tønderhus med ca. 100 deltagere, hvor museumsinspektør, arkitekt Herz viste lysbilleder og fortalte om udgravningerne ved Solvig. Ved generalforsamlingen blev de to afdøde medlemmer af styrelsen, C. Schmidt, Døstrup, og J. Freudendahl, Brøns, mindet, og $\mathrm{i}$ deres sted valgtes fru Bahne Nicolaisen, Østerholm, og advokat Sv. Oksen, Skærbæk.

Den 10. 6. 72 havde vi en udflugt med egnsvandring på Sild med fæelles start fra Havneby og med lærer Anton Nielsen fra den danske skole i List som leder og kommentator, også efter kaffebordet på hotel Morsum Klev. Der var 60 deltagere, der startede i regnvejr, men snart kom solen og holdt på hele hjemturen.

Fhv. larer W. Leick $\mathrm{m}$. fl. fortsatter med affotografering af huse og gårde.

De lokale historiske foreninger $i$ de nordlige sogne fortsætter deres arbejde, i sxrlig grad i Skxrbxk med indsamling af gamle ting, nu fornylig en hjulplov, som Peter Petersen, Havneby, gør en stor indsats for at konservere og gøre i stand.

S. $N$.

\section{Sydslesvigsk amtskreds.}

Mandag den 7. februar 1972 blev der holdt møde i Slesvig i samarbejde med Gottorp amts lxrerkreds. Rigsbibliotekar Palle Birkelund holdt foredrag om »Joachim Wasserschlebe. En kendt dansk kulturpersonlighed fra det 18. århundrede $\%$.

Torsdag den 18. maj 1972 holdt amtskredsen sin generalforsamling på Dansk Centralbibliotek i Flensborg. Professor Troels Fink blev valgt som mødeleder. Formanden aflagde års- og kasseberetning, der begge blev godkendt. I tilknytning hertil bragte Historisk Samfunds formand, landsarkivar Peter Kr. Iversen, Abenrå, en hilsen fra den store forening og udtalte sin glæde over det arbejde, der blev udført indenfor amtskredsen her $\mathrm{i}$ Sydslesvig.

Forstander, overlærer frk. Anna Schrøder og pastor Flemming Møller stod til valg. De blev begge to genvalgt. Pens. skoleinspekter F. Dinsen Hansen fratrådte efter mange års arbejde $i$ styrelsen. Der blev rettet en særlig tak til ham. Under evt. blev programmet for sommeren drøftet og vedtaget. Efter kaffebordet talte dr. phil. G. Japsen, Historisk Institut $\mathrm{i}$ Arhus, om »Skolens andel $\mathrm{i}$ den nationale opdeling af Sønderjylland 1814-1848«. Der fulgte en livlig diskussion. 
Torsdag den 8. juni 1972 var vi på aftenvandring i Slesvig by. Et team fra Århus under ledelse af stud. mag. Jens Vellev var i gang med udgravninger på Sct. Michaelis' tomt. I tilknytning hertil samledes vi på bymuseet i Slesvig, hvor Dr. Theo Christiansen fortalte om museets historie samt om de forskellige udgravninger, der i sommer er i gang i Slesvig by.

I denne interessante sammenkomst på museet deltog i alt 80 personer. Turen sluttede med et kaffebord i Ansgar-Skolens mødesal. Her var pastor Parmann og frue varter.

Lordag den 1. juli 1972 kom til at stå som en særlig begivenhed $i$ amtskredsens historie. Den dag samledes vi på øen Nordstrand. Blanke Hans tog imod os med storm og kulde. I „Feddersens Gasthof « samledes vi omkring kaffebordet - der var da godt 40 personer. - Kapellan Peter Schmidt holdt foredrag over emnet "Nordfrislands gamle kirkehistorie, set fra Nordstrand«. Vi har alle hørt mere eller mindre om kirkens skæbne i Nordfrisland; ved denne sammenkomst fik vi om dette emne noget at høre, som kun en person, der har en grundig viden, kan tale om.

Institutlektor R. K. Holander var næste taler ved en "farisæer" $i$ Norderhafen. Desværre kunne vi ikke gennemføre den påtænkte vandring på øen. Stormen var for voldsom. Takket være R. K. Holanders spændende redegørelse blev hans indlxg den rigtige afslutning på vor »sommervandring «, hvilket pastor Flemming Moller gav udtryk for.

L. H.Sch. 


\section{Årsberetning og regnskab $1971-72$}

Ved Peter Kr.Iversen og Hugo Lildholdt.

Historisk Samfund for Sønderjylland holdt årsmøde søndag den 28. maj 1972 på »Tønderhus $\mathrm{i}$ Tønder. Mødet begyndte kl. 14, og der var mødt ca. 125 medlemmer.

Formanden, landsarkivar Peter Kr. Iversen, bød velkommen og foreslog som dirigent viceskoleinspektør W. Christiansen, Tønder, hvilket bifaldtes af forsamlingen. Dirigenten takkede for valget, og efter at have konstateret, at årsmødet var lovligt indvarslet, gav han ordet til formanden, som indledte med at udtale mindeord om Cornelius Schmidt, Døstrup, som i 16 år havde været formand for Tønder amtskreds. Forsamlingen mindedes Cornelius Schmidt ved at rejse sig. Derefter aflagde formanden folgende beretning:

Det har altid været rart ved årsmøderne at kunne berette om foreningens forskellige aktiviteter. Det er det også $i$ år, selv om vi ikke helt har kunnet nå op til sidste års rekord både med hensyn til omsæetning og produktion af bøger. Det ekstraordinære store salg i 1970-71 i forbindelse med de store tilskud medførte, at vort regnskab passerede den halve million. I beretnings- og regnskabsåret, der går fra 1. april 1971 - 31. marts 1972, er vi nået ned på det mere normale, men som det vil fremgå af regnskabet, er det dog stadig efter historiske foreningers forhold meget betydelige beløb, der er blevet os betroet at forvalte, nemlig kr. $427.000 \mathrm{kr}$.

Ved sidste årsberetning kunne vi nævne et medlemstal på 2.932, men samtidig kunne formanden, professor Troels Fink, oplyse, at ca. 50 medlemmer havde "glemt" at betale deres kontingent. Vi hørte ikke senere fra disse medlemmer, og de er derfor nu slettet $\mathrm{i}$ vort kartotek. Det reelle medlemstal i dag er 2.853, altså 79 færre end sidste år. Når vi tager de 50 tvivlsomme med i beregningerne, er medlemstabet dog kun ca. 30 . Selv om vi således har måttet notere en mindre medlemstilbagegang, er der dog ikke grund til de helt store klagesange. $\mathrm{Da}$ vi for nogle år siden på grund af vort store salg af den første billedbog havde en medlemstilgang på op mod 1.000, måtte vi nøgternt erkende, at der blandt disse mange nye medlemmer måtte være nogle usikre. $P_{a ̊}^{\circ}$ en måde er det forbavsende, at frafaldet ikke har været større. Det vidner om, at disse nye 
medlemmer har sat og sætter pris på Historisk Samfunds forskellige aktiviteter. Men vi vil naturligvis gerne have nye medlemmer for dem, der faldt fra. Trykkeomkostningerne stiger stadig, og jo flere vi er om at dele dem, des mere kan der også fås for pengene. Derfor vil vi også gerne i dette jubilxumsår bede vore medlemmer om at støtte foreningen ved at give en håndsrækning ved tegning af nye medlemmer.

Ser vi i øvrigt på året, der gik, bemærker vi, at Sønderjyske Årbøger udsendtes i 1971 i et omfang på 344 sider, hvilket gør den til den trediestørste årgang, idet kun 1957 (350 s.) og 1964 (536 s.) har været større. Der var i 1971255 sider egentligt artikelstof, der i tid strækker sig fra den tidlige middelalder til vor egen tid og i emnevalg fra trafik og forsvar til folklore, skole- og kirkehistorie. Der var $\mathrm{i}$ alt anvendt 45 sider på omtale og vurdering af nye bøger vedrørende sønderjysk historie, og på 32 sider omtaltes det arbejde, der udfolder sig $\mathrm{i}$ landsdelens historiske institutioner og virksomheder. Det er vort indtryk, at denne orientering værdsættes af vore læsere. Ved sidste årsmøde meddeltes, at Sønderjyske Årbøger herefter ville blive udsendt indbundet $\mathrm{i}$ et bind mod hidtil to hæftede halvbind. Derfor har medlemmerne ikke făet noget forårshæfte af Sønderjyske $\AA_{r}$ bøger, men i stedet for en lille tryksag: "Meddelelser*, som det er tanken fremtidig at udsende i maj umiddelbart før hvert årsmøde.

Vort andet tidsskrift, Sønderjysk Månedsskrift, har i 19721430 holdere eller 5 færre end sidste år. Også her gælder det åbenbart, at vi må være lidt mere ude om os for at få fat $\mathrm{i}$ nye holdere. For her făr disse da virkelig noget for pengene. I 1971 var omfanget i alt 528 sider, hvilket er ca. 100 sider mere end i 1970, og hertil kommer, at der på de tospaltede sider står betydelig mere tekst end på de almindelige enspaltede sider. Indholdet er, efter at Grxnsevagten er standset, udvidet med flere dagsaktuelle artikler, og Fr. Rudbecks granselandsdagbog findes nu ligeledes her. Den tilgang af nye holdere, der var ventet ved Grxnsevagtens standsning, har ikke helt svaret til forhåbningerne, og dette i forbindelse med tidsskriftets større omfang har medført et betydeligt underskud, og det har derfor været nødvendigt fra nytår at tage reb i sejlene, således at redaktionen foruden indtægterne fra abonnementet indtil videre får et tilskud på omkring $30.000 \mathrm{kr}$. at arbejde med. Disse midler fordeles ligeligt på den bevilling, som hidrører fra Hafnias jubilæumsgave, og på midler, som stilles til rådighed fra Dansk Kultursamfund. Men Hafniapengene er der allerede taget forskud på i 1971, og hvordan situationen tegner sig ved årsskiftet 1972-73, står endnu hen $i$ det uvisse. En forhøjelse af abonnementsprisen på f. eks. $10 \mathrm{kr}$. årligt kan ikke alene klare problemet. Den eneste virkelige hjxlp er mange nye holdere. Vi bør bringe mere oplysning ud til befolkningen om det virkeligt gode, folkelige, historiske og aktuelt orienterende tidsskrift, som månedsskriftet $\mathrm{i}$ de sidste par år er blevet.

I denne forbindelse er det vard at navne som et vidnesbyrd om Sønderjysk Månedsskrifts høje stade, at Dansk Historisk Fællesforenings år- 
bogspræmie, der for treårsperioden 1967-69 uddeltes på sammenslutningens årsmøde i Århus i september 1971, blev tildelt konsulent Aage Lauritsen, Ulbolle, for artiklen: Hedeby, Haddeby, Slesvig og Sli, der findes i årgang 1967. Det er naturligvis først og fremmest vor fynske ven, der tilkommer xren, men det må også være naturligt, at vi giver udtryk for vor glæde over, at denne inspirerende afhandling er publiceret $i$ et af vore tidsskrifter. Det er forste gang, en prxmieret afhandling har varet bragt $i$ Sønderjysk Månedsskrift, medens flere afhandlinger i Sønderjyske Arbøger har fået denne hædersbevisning.

Med hensyn til udgivelsen af bøger har vi måske været lidt lade i sammenligning med det foregående beretningsår, men til en del er det dog alligevel blevet. Forst og fremmest skal pastor A. Andersens udgivelse af Johannes Pistorius' brevbog nævnes. Udgivelsen omtaltes nærmere i sidste årsberetning, og her skal kun tilføjes, at dette store værk også har fundet en del købere blandt vore almindelige medlemmer og ikke blot blandt biblioteker og videnskabelige institutioner. Bogen, der er xeroxkopieret efter pastor Andersens meget omhyggeligt på to skrivemaskiner, den ene med graske typer, udarbejdede manuskript, vil nok en gang blive et samleobjekt for bibliofiler, men det, der for os tæller mest, er bogens høje videnskabelige standard. I den lille serie "Sønderjyske Levnedsløb «, som den er navngivet, har vi udsendt fortsættelsen af fhv. folketingsmand Jens Bladts erindringer under titlen: ». . . og så blev jeg folketingsmand «, en bog, der også er blevet godt modtaget af anmelderne. Ved bogens redaktion har overbibliotekar Gustav Auring medvirket. Hanne Poulsens bog om maleren Jes Jessen fra Åbenrå lykkedes det også at få koncentreret så meget, at den kunne udsendes $\mathrm{i}$ serien $\gg$ Sønderjyske Levnedsløb «. Også denne bog har fået gode anmeldelser, og salget går godt.

En bog lidt uden for vort sædvanlige program er »Sønderjylland 1970. Taler $i$ jubilxumsåret«, d.v.s. først og fremmest talerne fra den store Dybbel-fest. Tanken om bogens udgivelse er opstået i Sprogforeningens bestyrelse, dens realisering besluttedes af de nationale foreningers samarbejdsudvalg, medens Historisk Samfund fik overdraget det praktiske arbejde med udgivelsen. Redaktionsudvalg for bogen blev amtskontorchef J. P. Caspersen, rektor D. Keller Hansen, rektor A. Feilberg Jørgensen og landsarkivar Peter Kr. Iversen med nuværende seminarieadjunkt Gudmund Tybjerg som sekretær. Bogen har foreløbig givet et ganske betragteligt underskud.

Redaktionsudvalget har, som det fremgår af de fornylig udsendte *Meddelelser «, begyndt forarbejdet til en bog om danske, sønderjyske historikere $\mathrm{i}$ de sidste hundrede år. Denne bog skulle være foreningens egentlige jubilæumsskrift, men vi må allerede nu erkende, at det ikke kan blive fxrdigt til den 19. december, der er foreningens stiftelsesdag.

Vort smertensbarn, bind 3 af Abenrå bys historie, er stadig på trapperne. Det sidste af manuskripterne er nu ved at være afsluttet, og bindet skulle være færdigt inden næste årsmøde. I øvrigt er $\mathrm{i}$ forbindelse med udgivelsen 
af Abenrå bys historie opstået den tanke, at værket burde udvides med to bind, hvoraf det ene skulle omfatte Lojt sogn, det andet Ensted sogn, begge sogne dele af den nye Ảbenrå storkommune. Et par unge historikere har meldt sig som mulige medarbejdere.

Af andre bøger, som er under planlægning, skal nævnes en historisk billedbog, der skulle illustrere udviklingen i Sydslesvig fra 1920 til i dag, og en billedbog, der illustrerer udviklingen i Sønderjylland 1864-1920. Der kræves meget store økonomiske ressourcer for at kunne igangsætte så store arbejder, og påbegyndelsen vil derfor være afhængig af, om vi skulle have held til at modtage gaver $i$ anledning af jubilæet. Vi har ment, at Sydslesvig 1920 til i dag skal have førsterangen af de to bøger.

Også inden for vore Sønderjyske Levnedsløb * har vi tænkt på en lille bog, men da vi bliver nødt til at bruge mange penge til udgivelsen af historikerbiografierne, må vi nok udskyde udgivelsen til næste beretningsår.

Historisk Samfund bestiller jo imidlertid andet end at udgive bøger og tidsskrifter. Det talte ord betyder da heldigvis endnu stadig en hel del inden for foreningens virksomhed. Der har varet afholdt 9 møder (incl. vort årsmøde), og der har været arrangeret 6 udflugter og en historisk sondag, den sidste i Ảbenrå amt. Den store udflugt, der som sædvanlig var arrangeret af næstformanden, viceskoleinspektør Stenz, og i dennes forfald ledet af seminarielektor, dr. phil. Sig. Schoubye, gik til Sydvestfyn den 5. september og havde samlet 150 deltagere. I alt har der $i$ udflugter, incl. Historisk søndag, deltaget ca. 700 personer, og i møderne har deltagerantallet været ca. 560. Ligesom sidste år har der på landsarkivet, med arkivar Viggo Petersen som leder, været arrangeret et vejledende kursus i personalhistorisk arbejde. Deltagerantallet var 15.

Historiske Samlinger, der har til huse på landsarkivet, vil efter endt ombygning af det gamle magasins stueetage få gode opbevarings- og arbejdsrum. Antallet af indsamlede billeder og negativer har $i$ det forløbne beretningsår været 2713 eller noget mindre end sidste år, men der er mange gode billeder blandt nyerhvervelserne. Samlingen af topografiske billeder vokser mest, men der har også været en god tilvækst af personbilleder. $\mathrm{Vi}$ er naturligvis forst og fremmest interesseret $i$ billeder af mere fremtrxedende personligheder, men fotografier af ganske almindelige mennesker har også vor store interesse. Ingen af os kan i dag sige, hvilke personbilleder, der bliver eftersøgt om f. eks. 100 år. Slægtsforskerne vil ganske givet ikke nøjes med de tørre årstal om deres afdøde aner; man vil have billeder af dem, måske endda film og lydbånd. Registeringen af billeder er som tidligere år udført af fru Vibeke Gribsvad. Arbejdet med fotograferingen af de gamle bygninger $\mathrm{i}$ Tønder amt fortsætter under lærer Leicks ledelse, men det har knebet lidt at finde medarbejdere i nogle sogne. Samlingen af lydbånd har $\mathrm{i}$ år kun haft en tilvækst på et par bånd, men det kan oplyses, at der er skrevet kontrakt med lektor Karl Clausen og Statsradiofonien om placering af førstnævntes mange bånd med optagelser af sønderjyske folkesange, rim og remser i Historiske Samlinger. Driften har kunnet klares ved et tilskud fra Dansk Kultursamfund. 
I forbindelse med omtalen af Historiske Samlinger skal endvidere nævnes den udstilling af gamle fotografier for tiden indtil 1920, som i samarbejde med Danmarks Radio, de byhistoriske samlinger i Haderslev, Ảbenrå og Skæærbak samt de fire museer i købstæderne arrangeredes på Abenrå museum i dagene den 19.-21. november. Den skulle have været afholdt på et tidligere tidspunkt, men folketingsvalget og andet medførte en udskydelse. Om tidspunktet i november så blev bedre, kan jo altid diskuteres, idet den omtale, som TV havde givet tilsagn om, måtte vige for helt anderledes aktuelt stof, nemlig den voldsomme snestorm og dens følger. Men udstillingen virkede dog derhen, at der afleveredes en del billeder, og vi fik oplysninger om billeder og film på private hænder. Vigtigst var måske dog, at samlingerne og museerne her $\mathrm{i}$ landsdelen havde et godt samarbejde om dette arrangement, som $\mathrm{i}$ alt kostede godt $7.000 \mathrm{kr}$. Udstillingen har $i$ januar været vist i Skxrbxk, og selvom billederne og forstørrelserne nu er ved at blive delt mellem de samarbejdende institutioner, vil det være muligt uden alt for store omkostninger at stille udstillingen op andre steder.

Historisk Samfund er medlem af Sammenslutningen af lokalhistoriske Foreninger og dermed af Dansk Historisk Fællesforening, der varetager fxlles interesser over for myndighederne, og hvis årsmoder er forum for udveksling af erfaringer. I år var Historisk Samfund repræsenteret på årsmødet, der afholdtes den 2.-5. september i Århus, af kassereren, direktør H. Lildholdt, rektor Keller Hansen, rigsarkivar Johan Hvidtfeldt, arkivar Viggo Petersen og landsarkivar Peter Kr. Iversen.

Vi har igen holdt status over Historisk Samfunds arbejde. Det har, skønner vi selv, været et godt arbejdsår, hvori vi med hensyn til omfanget af Sønderjyske Arbøger og Sønderjysk Månedsskrift nok har været lidt for flotte, således at vore beholdninger er gået tilbage med knap $13.000 \mathrm{kr}$. Såfremt disse penge stod til fri disposition, havde et sådant merforbrug også helt været i sin orden, men pengene er øremærket - de $25.000 \mathrm{kr}+$ renter stammer fra Ingrid-Fondet til en konkret forskningsopgave, og resten er af styrelsen hensat til udgivelsen af billedbog II, Sønderjylland 1864-1920. Derfor har styrelsen som indledende bemærket måtte træffe den lidt triste beslutning, at Sønderjysk Månedsskrift og Sønderjyske Årbøger må holdes inden for lidt mere beskedne økonomiske rammer, som ikke må overskrides.

Som vi plejer, vil vi også i år slutte med at rette en tak til medarbejderne, og denne tak gælder både medarbejderne på kontoret og bidragyderne til vore tidsskrifter og bøger. Men først og fremmest står vi i stor taknemmelighedsgald til fonds, institutioner og Sønderjyllands amtsråd for den meget betydelige økonomiske støtte, som har muliggjort arbejdet. Og lad mig slutte med at bringe en særlig tak til forsikringsselskabet Hafnia, som forleden gav os det tidligere omtalte tilskud på $50.000 \mathrm{kr}$., som er tænkt anvendt til Sønderjysk Månedsskrifts udgivelse, og lad mig endvidere nævne, at forleden dag kom der dumpende et brev ind med en 
check på $5.000 \mathrm{kr}$. fra Den sønderjyske Fonds Legat som en hilsen i anledning af jubilxet. En sådan uansøgt hjxlp er dobbelt velkommen. Vi er legatbestyrelsen stor tak skyldig. Disse $55.000 \mathrm{kr}$. er ikke medtaget $i$ det regnskab, som kassereren nu vil aflægge, idet regnskabet går fra 1. april - 31. marts, men det er rart at vide, at pengene er der, og vi vil tilstrabe, at de bliver anvendt på en god måde til det historiske arbejdes trivsel her $i$ landsdelen.

Beretningen godkendtes, og derefter gav dirigenten ordet til kassereren, bankdirektør $H$. Lildholdt, der aflagde regnskabet (jvf. omstående), som enstemmigt blev godkendt af forsamlingen.

Under punkt 3, valg, meddelte dirigenten, at Chr. Stenz, S. Schoubye, Hans-Iver Toft, Inger Bjørn Svensson og G. Japsen var på valg, og de blev alle genvalgt. Som nyt medlem af styrelsen foreslog formanden arkivar Dorrit Andersen, som i forvejen er medlem af redaktionsudvalget for Sønderjyske Ärbøger. Valget godkendtes. Revisorerne, skatterådsformand Sv. Lyck og sparekasseekspeditionssekretær C. O. Henningsen, genvalgtes. Under "Eventuelt « redegjorde næstformanden, viceskoleinspektør Chr. Stenz, for planerne for egnsvandringen, som finder sted den 9. og 10. september og skal gå til Ditmarsken.

Lærer Ib Andersen, Felsted, og lærer Helge Jacobsen, Haderslev, stillede spørgsmål om månedsskriftets indhold og udseende, og fru Inger Bjørn Svensson svarede.

Efter kaffebordet fortalte Tønder museums leder, dr. phil. Sig. Schoubye, om det nye museum, som deltagerne bagefter havde lejlighed til at besøge, og sluttelig afholdtes under ledelse af $\mathrm{dr}$. Schoubye, amtmandinde Tryde Haarløv og dr. pharm. Hans-Iver Toft en byvandring, hvor nogle af Tønderfondens nyrestaurerede huse samt fondens udstilling i Handelsbankens bygning blev forevist. 


\section{Regnskab for året 1. april 1971 til 31. marts 1972}

Indtagter:

Beholdning pr. 1.4.1971 . 116.264,68

Medlemsbidrag $\ldots \ldots \ldots .56 .981,41$

Salg af skrifter ...... $57.058,26$

Tilskud til skrifter ..... 71.596,00

Sønderjysk Månedsskrift:

Abonnementer, annoncer 47.637,25

Tilskud o. 1. ....... 24.095,00

Andre tilskud ........ 39.144,95

Renter ........... 10.553,31

Moms o. 1. ........ $3.750,00$

Kr. $427.080,86$

\section{Udgifter:}

Sønderjyske Årbøger .... 81.041,61

Skrifter .......... 74.958,00

Sønderjysk Månedsskrift. . 94.941,02

Kontorhold ......... 10.354,03

Lonninger .......... $36.528,81$

Møder o. 1. ......... $5.996,80$

Repræesentation $\ldots \ldots \ldots \quad 2.168,95$

Amtskredsene ....... $4.250,00$

Kontingent S.L.F. ...... $1.749,60$

Forsikringer o. 1...... 1.171,00

Porto o. 1. ........ $3.476,32$

Diverse .......... $6.554,20$

Egnsvandring $\ldots \ldots \ldots \ldots \quad 487,31$

Beholdning pr. 31.3. 1972 103.403,21

Kr. $427.080,86$

\section{Status pr. 1. april 1972}

Aktiver:

Beholdning ......... 103.403,21

Udestående for salg..... $3.000,00$

$\div$ balance.......... 22.971,73

Kr. 129.374,94
Passiver:

Ingrid-Fondet for Sønderj. 26.776,32 Henlagt til skrifter,

moms o. 1......... 100.000,00

Egnsvandringsfond ..... 2.598,62

Kr. 129.374,94

Ảbenrå, den 18. maj 1972.

Hugo Lildholdt.

Foranstående regnskab er revideret med bilagene, girokonto og bankbøger og er fundet $i$ orden.

Åbenrå, den 24. maj 1972.
Sv. Lyck.
C. O. Henningsen. 


\section{Tillæg til medlemsfortegnelsen}

Efterfølgende supplement til den i årene 1955 til 1971 offentliggjorte medlemsfortegnelse for Historisk Samfund for Sønderjylland medtager som de foregående år $i$ afgangslisten kun de afdøde medlemmer, hvis død er kommet til vort kendskab, medens tilgangslisten omfatter alle nye medlemmer $\mathrm{i}$ alfabetisk rækkefølge.

Pr. 1. oktober 1972 udgør medlemstallet 2867, der fordeler sig på Sønderjylland og det øvrige land samt udlandet som følger:

Haderslev by $\ldots \ldots \ldots \ldots \ldots \ldots 193$

Haderslev amt ............ 358

Sønderborg by $\ldots \ldots \ldots \ldots \ldots \ldots .96$

Sønderborg amt $\ldots \ldots \ldots \ldots \ldots .172$

Tonder by $\ldots \ldots \ldots \ldots \ldots \ldots \ldots \ldots$

Tønder amt ............ 275
Åbenrå by $\ldots \ldots \ldots \ldots \ldots \ldots 265$

Åbenrå amt ............. 259

Sydslesvig $\ldots \ldots \ldots \ldots \ldots \ldots .179$

Storkøbenhavn .......... 301

$\varnothing$ vrige Danmark ............ 591

Udland ................. 26
Andersen, Anders, fhv. landmand, Visby

Dirksen, H., dr. med., Broager.

Hansen, Harry, overlæge, Haderslev

Hvidtfeld, Erik, købmand, Vejle

Høfring, P., sognepræst, T'ange

Jacobsen, Marie, frøken, Ảbenrå.

Jensen, Johs., statskonsulent, Åbenrå

Johansen, Alfred, købmand, Gråsten

Karkov, Alfred, lærer, Løgumkloster

Lorenzen, John Nis, overlæge, dr. med., Tonder

Lüddens, Elisabeth, fru, Rostrup ved Oldenburg
Andersen, Poul, Rens

Andresen, Karl, højskoleforstander, Jaruplund

Asmus, Helmuth, lærer, Lyksborg

Bendix, Georg, cand. theol., Hindballe, Gram

Billund, Marie, fru, Ãbenrå

Bock, Andreas, Bredebro

\section{Tilgangsliste}

Boldt, Flemming, Fredensborg

Bracke, Aage, lærer, Hørup, Sydslesvig

Brodersen, Karsten, cand. jur., Slesvig

Cederholm, Alexander, snedkermester Augustenborg

Cornelsen, Peter, postbud,

St. Jyndevad 
Damm, Ingeborg, fru, Gøtterup

Devantier, Bent, Tønder

Dollerup, Bent, stud. mag., Brabrand

Dreyer, Valdemar, læge, Sjellerupskov

Ebbesen, Rasmus L. Fink, sognepræst, Skrydstrup

Emborg, J. C., læge, Gråsten

Erichsen, Klaus, stud. mag., Århus

Eriksen, Anker, gårdejer, Halk

Fangel, Henrik, adjunkt, Ābenrå

Freudendahl, Chr., gårdejer, Mjolden

Fræmohs, Erik, kontorchef, cand. jur., Silkeborg

Fuhrmann, Siegfried, køkkenleder, Flensborg

Gotthardsen, Frede, lærer, Løgumkloster

Gravgaard, Dieter, Århus

Hansen, Andr., skoleinspektør, Rensborg

Hansen, Hans P., varkforer, Ulkeboldam

Hansen, Helene Sander, Glostrup

Hansen, Henrik J., gårdejer, Hønkys

Hansen, Therkel, gårdejer, Obbekjær

Hansen, Thorvald Lund, landmand,

Sdr. Vilstrup

Hansen, Torben Bagge, Abildgård, Fjelstrup

Harsberg, V., amtskommunaldirektør, Ảbenrå

Hein, Stig, overlæge, Haderslev

Hersbøll, Knud, dyrlage, Jejsing

Holst, Kirstine, fru, Kestrup

Husum, 'Thorkild, adjunkt, Alestrup

Hviid, Helene, fru, Ābenrå

Häggmark, Gunnar, stud. fil., Stockholm

Haase, Ingolf, sergent, Tonder

Jacobsen, Ellen Rossen, gårdejer, Ārslev
Jensen, Lars Gaunø, stud. mag., Arhus

Jessen, Jørgen, seminarielektor, Tjørring

Jessen-Klingenberg, Manfred, dr., Kronshagen

Johansen, Fr., Brændstrup

Jørgensen, Verner, sygeplejeassistent, Tønder

Klaus, Elisabeth-Charlotte, bornehaveleder, Flensborg

Kristensen, Henry, varmemester, Løgumgård

Larsen, Erik E., Skodborghus

Larsen, Johannes, lærer, Jejsing

Lassen, Thomas, Ārhus N.

Lausten, Niels, købmand, Broballe

Leppien, Jørn-Peter, Kronshagen

Linding, Kirsten, Haderslev

Lund-Petersen, Peter, stud. mag., Visby $\mathrm{J}$.

Lykke-Kjeldsen, Niels, stud. mag., Esbjerg

Lonstrup, Jacob, stud. mag., Viby

Madsen, Holger, landmand, Agerskov

Matzen, Peter, læge, Ảrhus

Mikkelsen, Elise, skolepædagog, Haderslev

Monrad, H., skoleinspektør, Sommersted

Møller, P. A., gårdejer, Skærbæk

Moller, Torp Friis, gårdejer, Årslev

Nielsen, Klaus, stud. mag., Århus

Nohns, Jørgen, Padborg

Norgaard, Misse, fru, Birkelev

Oxlund, Jens, stud. mag., Ndr.

Randlev

Permin, Torben, advokat, Esbjerg

Petersen, F. W., stud. mag., Viby J.

Pedersen, H. Hedelykke, rektor Tronder

Petersen, Martin, gårdejer, Forballum

Petersen, Peter, forvalter, Ābenrå

Petersen, Poul, gartner, Uge 
Rasmussen, Egon, gymnasielærer, Flensborg

Rasmussen, Holger, overtoldassistent, Starup

Rasmussen, Thorkild Heilskov, cand. phil., Balle

Runekær, Peter, overlærer, Næstved

Råby, Hans Peder, stud. mag., Viby J.

Sahl, Hans, gårdejer, Kværsløkke

Schack-Nielsen, W., direktør, København

Schmidt, Jens Chr., stud. mag., Århus

Schultz-Jørgensen, L., tømrermester, Holte

Skygebjerg, Dorrit, lærerstuderende, Tønder
Smith, Ole, redaktør, Flensborg

Sønderborg kommunes biblioteker, Sønderborg

'Thaisen, 'Thomas, sogneprest, Brons

Thomsen, Christian, kontorist, Rødekro

Thomsen, Inga, stud. mag., Ārhus

Thomsen, Viggo Vandkær, skoleinspektør, Lysabild

Toft, Hans, landmand, Emmerlev

Tybjerg, Gudmund, seminarieadjunkt, Jejsing

Uhre, Hans Borgen, lærer, Tønder

Wang, Jørgen, lektor, Sønderborg

Vogensen, Ole, advokat, Ābenrå.

Vollertsen, Ernst, overlærer, Lyrskov 

